\title{
BIOLOGICAL DIVERSITY AND ALBERTA LAW
}

\section{P.S. ELDER}

Biological diversity refers to the rich variety of all life forms presently on Earth. It is important to preserve and maximize biological diversity, because of its intrinsic value and its value to human survival and wellbeing. In order to do so, the author argues, a broad ecosystem management approach to species conservation is necessary.

Numerous Alberta statutes are examined comprehensively to determine their effects and potential effects on biological diversity. The ecosystem management approach to species conservation is not prominent in Alberta law. Outside of National Park land, very little of Alberta's area offers protection for biological diversity. While the administration of some Acts (such as the EPEA and the Natural Resources Conservation Act) shows promise, a lack of specific duties permits decisions adverse to biological diversity. Changes to Alberta's planning legislation may be beneficial, through the regulation of development on private land. Because of the prime importance given to economic development in various Alberta statutes, the possibility exists for significant adverse impacts to biological diversity.

The author recommends a number of legal reforms. These include the addition of explicit purpose sections in relevant legislation, the imposition of a positive duty on decision-makers to consider sustainability and biological diversity, and the creation of incentive programs to encourage private property owners to set aside habitat areas.
L'expression "diversité biologique» désigne la richesse des types biologiques existant sur notre planète. Il est important de préserver et de maximiser cette diversité, en raison de sa valeur intrinsèque et de son importance à la survie et au bien-être de l'espèce humaine. Pour ce faire, soutient l'auteur, il est impératif d'adopter une approche de gestion écosystémique globale.

$L$ 'auteur examine plusieurs lois albertaines pour déterminer leur incidence réelle et possible sur la diversité biologique. La conservation des espèces par la gestion écosystémique n'est pas une priorité dans les lois de la province. À l'extérieur des parcs nationaux, très peu de régions assurent la protection de la diversité biologique en Alberta. Bien que l'application de certaines lois (EPEA et Natural Resources Conservation Act) se montre prometteuse, l'absence d'obligations spécifiques autorise des décisions contraires à la diversité biologique. Il serait peut-être opportun d'envisager certaines modifications, en réglementant l'aménagement des propriétés foncières privées, notamment. La diversité biologique pourrait pátir de l'importance primordiale que les lois albertaines accordent au développement économique.

$L$ 'auteur recommande un certain nombre de réformes juridiques - l'inclusion de dispositions explicites dans les lois pertinentes, l'imposition aux décideurs du devoir positif de considérer la viabilité de l'environnement et la diversité biologique, et la création de programmes incitatifs visant $\dot{a}$ encourager les propriétaires particuliers à préserver certains habitats.

\section{TABLE OF CONTENTS}

I. INTRODUCTION . . . . . . . . . . . . . . . . . 294

II. THE DAMAGE TO BIOLOGICAL DIVERSITY . . . . . . 296

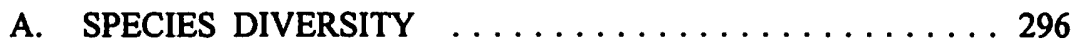

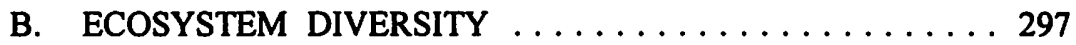

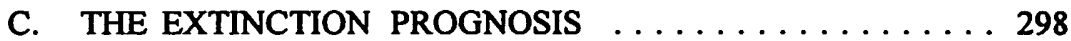

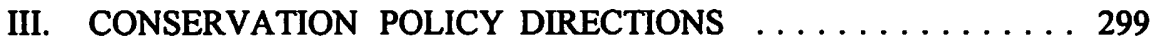

A. CONSERVATION LEGISLATION

— THE AMERICAN APPROACH . . . . . . . . . . 299

Professor of Law, Faculty of Environmental Design, University of Calgary. I would like to thank Stephen Herrero and Janet Keeping for reading the draft manuscript. Any remaining errors are solely my responsibility. 
B. BEYOND ENDANGERED SPECIES LEGISLATION $\ldots \ldots 302$

C. BIODIVERSITY MANAGEMENT OF ALL

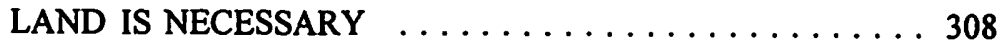

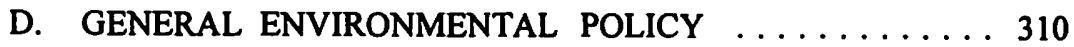

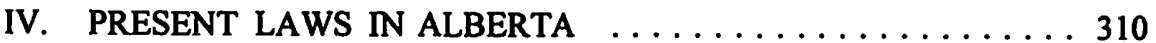

A. PROTECTED AREAS LEGISLATION $\ldots \ldots \ldots \ldots \ldots 311$

B. PLANNING LEGISLATION $\ldots \ldots \ldots \ldots \ldots \ldots \ldots \ldots$

C. EPEA, THE BOARDS AND THE

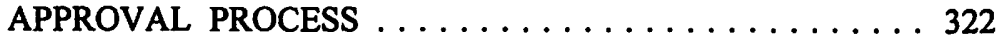

D. WILDLIFE LEGISLATION $\ldots \ldots \ldots \ldots \ldots \ldots \ldots \ldots 330$

E. PUBLIC LANDS LEGISLATION $\ldots \ldots \ldots \ldots \ldots \ldots 333$

F. PRESENT AND PROPOSED

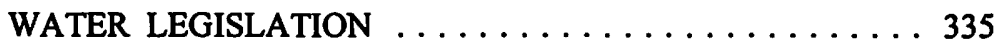

G. AGRICULTURAL LEGISLATION $\ldots \ldots \ldots \ldots \ldots \ldots 339$

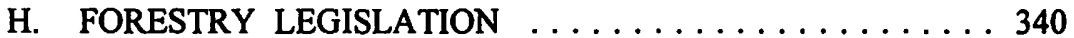

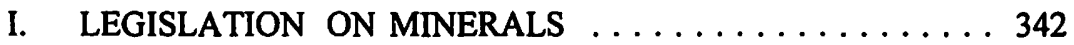

J. MISCELLANEOUS LEGISLATION $\ldots \ldots \ldots \ldots \ldots \ldots 344$

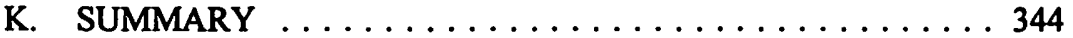

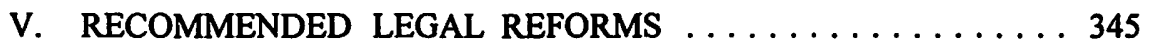

VI. CONCLUSION ..................... 350

Extinction is quite literally a fate worse than death.'

\section{INTRODUCTION}

Earth's physical limits increasingly present themselves. Increasing human population, industrialization and consumption patterns have created a global crisis with many faces - toxic pollutants in every ecosystem, threats of human-induced climate or atmospheric change, widespread habitat destruction. Environmental degradation threatens millions of people with death and millions of species with extinction. "[N]ever before has the world been more polluted and have global natural resources been more exploited than in the twenty years following the Stockholm conference [the 1972 UN Conference on Human Environment]."2 And this, in spite of many international treaties and cooperative activities.

It is our generation's task to stop the slide toward environmental catastrophe. One important aspect of the crisis is the increasingly rapid rate of extinction of many species. Humanity's future, like that of all life on the planet, rests on healthily

1 American Senator, 119 CONG. REC. 25,670 (1973) (as cited in R. Littell, Endangered and Other Protected Species (Washington: Bureau of National Affairs, 1992) at 4).

2 A. Muller-Helmbrecht, Coordinator of the UNEP Secretariat of the Convention on the Conservation of Migratory Species of Wild Animals, "The Bonn Convention and EECONET" in G. Benneth, ed., Conserving Europe's Natural Heritage Towards a European Ecological Network (London: Graham \& Trotman, 1994) at 195. 
functioning natural ecosystems. This means that, without biological diversity, the human race is imperilled.

Biological diversity refers to the rich variety of all life forms presently on Earth. ${ }^{3}$ It, and its preservation, can be conceptualized in various ways. This article will first argue the case for a broad, ecological diversity perspective and hence an ecosystem management approach to species conservation. From this point of view, and also more generally, it will assess the potential of Alberta law to affect biodiversity. Shortcomings will be identified. Some possible policy solutions will be offered, central to which will be the need for strong governmental planning and leadership. ${ }^{4}$ Of paramount importance is the fact that, without recruiting privately owned land to the cause, the battle to maintain biodiversity in Alberta could be lost.

The discussion will assume the need to maximize biodiversity, for a whole range of "ecological, economic, recreation and health, scientific, education, cultural and spiritual benefits." It is the right thing to do, because of its intrinsic value, as well as being vitally important for human survival and wellbeing. Legion are the examples of economic benefits, including those of many lifesaving pharmaceutical products. ${ }^{6}$

It is also important to understand the incalculable benefits which life itself has provided for Earth's inhabitants. Without necessarily accepting the Gaia hypothesis that the planet itself is a living organism, it is true that living organisms have created Earth's present atmosphere and the ozone layer (without this protection from deadly solar radiation no land plants or animals or primary producers near the ocean surface could survive). "Life forms create and maintain soil, recycle nutrients and play a critical role in maintaining the balance of oxygen and carbon dioxide." Life on Earth helps with climate regulation, including the hydrological cycle. Many pollutants are broken down biologically. Through chemical reactions, life forms were even responsible for the creation of iron deposits (photosynthetic organisms oxidized iron in the ocean) and for concentrations of silicon, manganese, copper and sulphur. ${ }^{8}$

The Global Convention on Biodiversity (1992) defines biodiversity as "the variability among living organisms from all sources, including, inter alia, terrestrial, marine and other aquatic ecosystems and the ecological complexes of which they are part..."

The discussion herein is intended to supplement the excellent earlier article by $C$. Rankin \& $M$. M'Gonigle, "Legislation for Biological Diversity: a Review and Proposal for British Columbia" (1992) 25 U.B.C. L. Rev. 277. Public Advisory Committee, Special Places 2000: Alberta's Natural Heritage (Edmonton: The Committee, Nov. 1993) at 5.

N.R. Farnsworth, c. 9 in E.O. Wilson, Biodiversity (Washington: National Academy Press, 1988) at 83 states that 25 percent of U.S. prescriptions have ingredients from "higher" plants (\$8 billion worth in 1985), although only a handful of plants (less than 100) had yet been exploited (at 93). E.O. Wilson, The Diversity of Life (Cambridge, Mass.: Belknap Press of Harvard, 1992) [hereinafter Life] at 283-84 claims that 40 percent of drugs prescribed in the U.S. are organism-derived. 


\section{THE DAMAGE TO BIOLOGICAL DIVERSITY}

Biological diversity should be approached on at least three different levels. Intuitively, people first associate the concept with the diversity of a vast number of species. (A species is a group of organisms, so genetically similar that they can interbreed and produce fertile offspring. ${ }^{9}$ ) This may be the heart of the matter, but in order that species be viable and capable of some adaptation to their environment, ${ }^{10}$ there must be genetic diversity within each population. The dangers of in-breeding are well-known.

At the same time, species live within a complex web of relationships with each other and their physical environment. The best-known expression of this complex is the ecosystem, each one of which, even at a small scale of classification, is home to many species. (An ecosystem is "a dynamic complex of plant, animal and micro-organism communities and their non-living environment interacting as a functional unit."'1) Without ecosystem diversity, the various communities of organisms would not have access to the required ecological processes such as nutrient or water cycles or energy flows. Many species can survive only within one specific ecosystem.

Thus, genetic, species and ecosystem diversity are all interdependent. On a more holistic level, one might also envisage landscape diversity over time, described for forests as "the pattern of ecosystem differences in an area where the forests are at various stages of the life cycle." 12

\section{A. SPECIES DIVERSITY}

In spite of sophisticated modern science, no one knows how many species there have ever been or are today. Possibly up to four billion species have arisen in history, ${ }^{13}$

9 WWF-World Wide Fund for Nature, The Importance of Biological Diversity (Toronto: WWF, 1990). Although the biological concept of species is the most popular, other competing definitions include the phylogenetic and the cohesion concepts. See K. D. Hill, "The Endangered Species Act: What Do We Mean by Species?" (1993) 20 Bos. Coll. Env. Affairs L. Rev. 239 at 249-53.

It should be realized, however, that although evolution through natural selection is very powerful, once species form, they tend not to change too much. The imperative is not "change or die," but rather "find suitable habitat (move) or die." Extinction ensues if no suitable habitat can be found.

Significant evolution occurs mostly in the face of new opportunity, such as an event which empties the fairly full niches of a mature ecosystem, not so much in a species' response to changes in the environment. See N. Eldredge, The Miner's Canary: Unravelling the Mysteries of Extinction (New York: Prentice Hall Press, 1991) at 9-11. 
although almost all (99+ percent) have gone extinct through natural processes. ${ }^{14}$ About 1.5 million existing species have been identified and the distinguished biologist $\mathrm{E}$. $\mathrm{O}$. Wilson estimates the possible total is within the order of magnitude of 10-100 million. ${ }^{15}$ No one, he asserts, knows which figure is closer to the mark. Erwin has suggested that there could be $30-50$ million species of insects alone. ${ }^{16}$ Considerable taxonomic field research remains to be done.

In Canada, 140,000-300,000 species are thought to exist, of which only one half have yet been identified. ${ }^{17}$ Although the status of most Canadian species has not yet been determined, the Committee on the Status of Endangered Wildlife in Canada has listed some 255 vertebrates and plants as being extinct, extirpated (no longer found in the wild in Canada) or at some risk of extinction. ${ }^{18}$

\section{B. ECOSYSTEM DIVERSITY}

Our country is also estimated to contain up to 25 percent of the world's wetland area ${ }^{19}$ although it is estimated that one seventh of the original area, or some 20 million hectares, has been lost. This includes over half of the prairie potholes ${ }^{20}$ so important to migrating waterfowl. Canada also contains almost 20 percent of Earth's wilderness, 20 percent of its fresh water and 10 percent of its forests. ${ }^{21}$ The southern prairie is one of three areas (the others are southern B.C. and the Windsor-Quebec City corridor) where Canada's endangered species are concentrated. ${ }^{22}$ Canada's northern ecosystems may be especially vulnerable to the apparent trend of global warming. ${ }^{23}$

As well as the slow, "background" rate of extinction, some five major extinctions and several minor waves have been identified from the fossil record. Various causes have been suggested for the rapid events (over hundreds of thousands of years, in some cases), many centering around apparent climate change, due to: changes in the gaseous composition of the atmosphere; collisions of heavenly bodies with Earth; huge volcanic eruptions; changes in solar radiation, the planet's orbit or the earth's magnetic field. Continental drift or break-up played a significant role as well, whether because of the rising or subsidence of large areas, or movement from one temperature zone to another. See Eldredge, supra note 10; and D.K. Elliott, ed., The Dymamics of Extinction (New York: Wiley, 1986). Life, supra note 6 at $132,346$. T.L. Erwin, c. 13 in Wilson, Biodiversity, supra note 6.

1 Federal-Provincial-Territorial Biodiversity Working Group, supra note 7 at 9, offers the low number, while Natural Resources Canada estimates the higher one (Natural Resources Canada, supra note 12 at 23). The difference appears to be in the number of unknown viral and bacterial species which are assumed to exist (Hon. Anne McLellan, Minister of Natural Resources Canada, pers. comm., Jan. 31, 1995) [hereinafter Min. of Nat. Res., pers. comm.].

Federal-Provincial-Territorial Biodiversity Working Group, ibid. at 9. A valuable source of information in the Canadian context, T. Mosquin et al., Canada's Biodiversity (Ottawa: Canadian Museum of Nature, 1995), has just become available. Environment Canada, The Federal Policy on Wetland Conservation (Ottawa: Environment Canada, 1991) at 3.

Ibid. at 4. 
Ecologists themselves are increasingly aware of gaps in their knowledge. The difficulty of understanding or making predictions about such complex open natural systems has been more clearly seen in the aftermath of chaos theory. "Nature, many have begun to believe, is fundamentally discontinuous and unpredictable. ${ }^{124}$ It is no longer assumed that a natural series of successional stages leads inevitably to a predictable climax ecosystem. Steady climax states are themselves transitory, and more than one of them could develop in the first place. Although diversity may be "the property that makes resilience possible," ${ }^{25}$ "[t] $]$ he relation between biodiversity and stability is a grey area in science. ${ }^{126}$ The enormous diversity in the tropical rainforest, for example, means that there are countless tiny ecological niches. This means that individual species are fragile and may be endangered by a very small change in their physical environment.

\section{THE EXTINCTION PROGNOSIS}

In spite of the uncertainties just mentioned, some generalizations can be made. Present global trends are highly ominous. Although many assumptions have to be made in order to predict species losses, ${ }^{27}$ the range of predictions is sobering, ranging from 20-50 percent of species in the world by various dates up to $2100 .{ }^{28}$ In Europe, "an estimated 22 percent of higher plants, 52 percent of fish and 42 percent of mammals are threatened with extinction." 29 This rate and magnitude of species extinction are of an entirely different character than that of the past. For one thing, extinction is proceeding much more rapidly than in almost any other era. ${ }^{30}$ For another, it is almost entirely caused by human action. Next, in principle, massive extinctions could be substantially avoided. ${ }^{31}$ As well, since the overwhelming cause of these extinctions is human destruction or degradation of habitat, much of the raw material for regeneration could be permanently ruined. This will significantly inhibit the rapid, diverse speciation which filled the new or vacant ecological niches after past mass extinctions. In the present case, the niches will already have been occupied by new monocultures or destroyed by physical development.

In sum, the evolutionary impoverishment of the impending extinction spasm, plus the numbers of species involved and the telescoped time scale of the phenomenon, may result in the greatest single setback to life's abundance and diversity since the first flickerings of life almost 4 billion years ago. ${ }^{32}$

D. Worster, "The Ecology of Order and Chaos" (1990) 14 Envir. History and Rev. 1 at 13.

Life, supra note 6 at 14.

Ibid. at 308-09.

For example, assumptions of the number of species existing, rates of habitat loss, relationships of area lost to the percentage of species lost, magnitude and rate of climate change.

A.E. Lugo, c. 6 in Wilson, Biodiversity, supra note 6 at 58.

J.-P. Rabaut, " The Council of Europe and EECONET" in Benneth, ed., supra note 2 at 182.

In the tropical rainforest, for example, human activity has caused extinctions between 1,000 and 10,000 times faster than the normal background rate (Life, supra note 6 at 280).

Wilson believes that the difference between passive acceptance of the situation and amelioration programs is a reduction of the loss from 25 percent of existing species to 10 percent (Life, ibid. at 342). This is a difference of millions of species.

N. Myers, c. 3 in Wilson, Biodiversity, supra note 6 at 33-34. 
Apart from the inherent tragedy of such a result, it is simply not known what results such extinctions might have. If some of these lost species are prerequisites for the existence of whole ecosystems ("keystone" species), biological collapse at some point could become irreversible.

Some people may be comforted by the thought that, since almost all known species have gone extinct over eons through natural processes, our actions are part of evolutionary history. They might think that another burst of speciation will more than replace those species which went extinct, because this has happened every time before. But, even if this might be true, the time required for such a development varied in the past from 20 to 100 million years. ${ }^{33}$ Furthermore,

it is becoming more apparent that the destruction of large numbers of the world's species will lower their diversity and allow "pests" to flourish because their natural enemies have been destroyed. Therefore, the destruction of large numbers of species will leave this an entirely different biological world than the one mankind originally inhabited. ${ }^{34}$

We now turn to a discussion of possible policy responses to this looming tragedy.

\section{CONSERVATION POLICY DIRECTIONS}

\section{A. CONSERVATION LEGISLATION - THE AMERICAN APPROACH}

As a transition to our policy discussion, two "early" American environmental statutes may be mentioned: the Wilderness Act of $1964^{35}$ and the Endangered Species Act. ${ }^{36}$

The U.S. Wilderness Act aimed at the preserving, for human use and enjoyment of solitude or of primitive, unconfined recreation, "areas where the earth and the community of life are untrammelled by man [sic], where man himself is a visitor who does not remain." ${ }^{37}$ To this end, it classified some 9 million acres of land as wilderness and required, over a ten year period, a review of National Forest primitive areas and roadless areas consisting of more than 5,000 acres in National Parks and Wildlife Refuges for possible inclusion in the system. The review was controversial, but by 1988 , the wilderness system included 88.7 million acres. ${ }^{38}$

$33 \quad$ Life, supra note 6 at 31 .

34 Erickson, supra note 8 at viii.

$35 \quad 16$ U.S.C. ss. $1131-36$ (1964).

36 Pub. L. No. 93-205, 87 Stat. 884 (1973) as am. (16 U.S.C. ss. 1531-1543 (1982)) [hereinafter the ESA]. The existence of the Marine Mammals Protection Act (Pub. L. No. 92-552, 86 Stat. 1027 (1972), 16 U.S.C. ss. 1361-1407 as am.) should also be noted. This Act, said to parallel the ESA (R. Lund, American Wildlife Law (Berkeley: University of California Press, 1980) at 96), protects all species of whales, dolphins, seals, polar bears, walrus, manatees and sea otters.

Supra note 35 at s. 1131 (c). For a history of American efforts to preserve wilderness, see A.D. Smith, Jr., "Wilderness and the Public Lands: an Introduction to the Symposium" (1979) 16 Idaho L.R. 379. See also B. Evans, "The Wilderness Idea as a Moving Force in American Cultural and Political History," ibid. at 389.

38 D. Rohlf \& D.L. Honnold, "Managing the Balance of Nature: the Legal Framework of Wildemess Management" (1988) 15 Ecol. L.Q. 249 at 251. 
Clearly, such major designations increase the likelihood of ecosystem-based preservation, especially since management agencies also have duties under the ESA. A caveat, however, is appropriate.

[T]he Wilderness Act ... represents somewhat limited goals of ecologic preservation. Preservation is envisioned only where areas will also provide ... outstanding user experience and scientific investigation is a matter of secondary concern. ${ }^{39}$

\section{Indeed,}

lawmakers believed they could have it two ways. Congress thought it could preserve pristine areas ... and yet avoid economic harm to ... development interests. Congress provided for mining, water and power development, grazing, and the control of fire and pests within wilderness boundaries..."

Nevertheless, this law's approach, in its immediate designation of wilderness areas, its timetable for consideration of additions, its creation of an affirmative duty to preserve or restore wilderness, ${ }^{41}$ although not necessarily in its grace period in some wilderness areas for the establishment of mineral claims (an overly liberal twenty years ${ }^{42}$ ), might be useful precedents for amendments to Alberta's protected areas legislation.

The ESA was enacted in 1973 at the suggestion of President Richard Nixon during the first phase of modern environmentalism. It was expected to have largely symbolic value. ${ }^{43}$ The ESA contemplates determination and listing by the relevant Secretary (usually of the Interior), on the basis only of the best scientific evidence, that species are endangered or threatened (i.e., likely to become endangered). Many types of species are covered by the ESA, including plants and all members of the animal kingdom, including invertebrates. The ESA purports to protect distinct populations where they are endangered. ${ }^{44}$

Various consequences follow once a species is listed. A recovery plan, including sitespecific management actions where practicable, is to be prepared and implemented. Priority here goes, so far as practicable, to those most likely to benefit therefrom.

39 Smith, supra note 37 at 387.

$40 \quad$ Rohlf \& Honnold, supra note 38 at 257-58.

$4 \quad$ Ibid. at 259.

42 The legal situation is fairly complex, depending on where the wilderness is located and who administers it: see G.W. Edwards, "Keeping Wildemess Areas Wild: Legal Tools for Management" (1986) 6 Va. J. Nat. Res. L. 101.

$43 \quad$ K.A. Kohm, ed., Balancing on the Brink of Extinction (Washington: Island Press, 1991) at 15.

4 The drafting of the definition of species to include "any distinct population segment ... which interbreeds when mature" has some interpretive difficulties which could cause some dispute. What about separated populations which do not interbreed? There are six populations of grizzly bears in the U.S. and some are geographically isolated. Arguably, these cannot be protected even if endangered, for unless breeding amongst themselves constitutes interbreeding, they are not "species" within this definition (D.J. Rohlf, The Endangered Species Act: A Guide to its Protections and Implementation (Stanford: Stanford Environmental Law Society, 1989) at 3839). 
Critical habitat is supposed to be listed concurrently with the determination that a species is endangered, ${ }^{45}$ after a consideration of the relevant impacts, including economic, of the designation. The import, export, taking, possession, transportation or sale of endangered fish and wildlife, or the violation of any regulation pertaining to them, is prohibited. The Secretary may, with the cooperation of any state, impose the same restrictions for threatened species. ${ }^{46}$ For endangered plants, no one may import, export, deliver, receive, transport or sell them, or remove from or maliciously destroy any species on areas under federal jurisdiction, or violate any regulation concerning them. Threatened plants may be similarly protected by regulation.

A general duty is placed on the Secretary, and on that of the Department of Agriculture in respect of the Forest Service, "to establish and implement a program to conserve fish, wildlife and plants, including ... endangered ... or threatened species...." 47 Measures to be used include the acquisition of land. All practicable cooperation with the states is required and federal assistance may be provided when appropriate agreements have been reached.

An important provision, s. 7, requires all federal agencies, with the help of the Secretary, to ensure that no action funded, authorized or carried out by it is "likely to jeopardize the continued existence of any endangered ... or threatened species or result in the destruction or adverse modification of" critical habitat. It will be noted, however, that privately owned habitat is unprotected from development unless it requires federal support or approval. ${ }^{48}$

On the other hand, the prohibition in s. 9 against "taking" endangered fish or wildlife has been interpreted to prohibit the destruction of their critical habitat, even on privately owned land. ${ }^{49}$

The affirmation by the U.S. Supreme Court in the famous snail darter case ${ }^{50}$ that economic benefit/cost considerations were irrelevant in the consideration of this section and that construction of the nearly completed Tellico dam should halt led to an addition to the ESA. A high level oversight committee (the "God Committee") was empowered to exempt specific projects from the ESA, although the procedure created is

ESA, supra note 36, s. 4(a)(3)(A). "As of 1991, only 16 percent of all listed species had designated critical habitat." This is at least partly because the ESA orders designation "to the maximum extent prudent and determinable" (A.A. Smith et al., "The Endangered Species Act at Twenty: An Analytical Survey of Federal Endangered Species Protection" (1993) 33 Nat. Res. J. 1027 at 1048-49).

ESA, supra note 36 , s. 9 (a)(1).

Ibid., at s. 5(a).

If "taking" in $\mathrm{s.} 9$ is broadened beyond hunting or gathering to include the indirect elimination of a species through interference with its habitat, this provision would clearly protect species on private land. The fact that an extensive interpretation of the term could render s. 7 unnecessary implies that Congress did not intend an extreme interpretation. Some American case law indicates a willingness to extend the meaning to some degree. See Rohlf, supra note 44 at 60.

Smith et al., supra note 45 at 1060.

Tennessee Valley Authority v. Hill, 437 U.S. 153 (1978). 
cumbersome, and has been rarely invoked. ${ }^{51}$ The Committee refused exemption for the Tellico dam, which was nevertheless completed after Congress passed an exemption attached as a rider to an unrelated money bill. ${ }^{52}$

Although there have been interpretive problems with the $\mathrm{ESA},{ }^{53}$ as well as considerable conflict over the Act's effect during pro-development administrations like President Reagan's, Congress has never significantly weakened its provisions. Nevertheless, its efficacy is in doubt (as will be shown momentarily).

The American ESA approach could be adapted, with improvements, to Canadian jurisdictions. The Canadian constitutional framework for species preservation would initially seem to imply more extensive provincial than federal action, except for the federal roles in fisheries, migratory birds, federal property and the Territories. This is not the place to speculate about possible federal powers under the "peace, order and good government" clause, but it should at least be noted that many endangered species inhabit ecosystems which span provincial or national boundaries. On any constitutional interpretation, however, an integrated federal and provincial approach is essential.

\section{B. BEYOND ENDANGERED SPECIES LEGISLATION}

\section{Fine and Coarse Filters}

This is, to be sure, only part of the necessary picture. Although endangered species legislation may help to maintain biological diversity, particularly if it preserves sufficient habitat for long term viability, an emerging consensus in the conservation community supports a broader approach than this "fine filter" method. ${ }^{54}$ First, the administration of the ESA tends to place higher priority on attractive or "charismatic" species, not the far more numerous and arguably more important "cogs and wheels"5s of ecosystems. Second, fragmented identification and management of all individual endangered species ${ }^{56}$ is simply not feasible. Given limited resources, "extraordinary efforts to save a very few species are misplaced in a world threatened with imminent loss of a great portion of its millions of species." ${ }^{57}$ Indeed, given limited resources, each new listing tends to dilute the support for others. Also, many of the very expensive recovery plans are for species of which less than 100 individuals remain. In many of these cases, little hope of permanent recovery exists. Third, we have to know

s!

Littell, supra note 1 at 75.

Ibid. at 11.

Supra note 44.

M.L. Hunter, "Coping With Ignorance: the Coarse Filter Strategy for Maintaining Biodiversity" in Kohm, ed., supra note 43 at 268.

A. Leopold, $A$ Sand County Almanac (New York: Oxford University Press, 1949), quoted in R.F. Noss, "From Endangered Species to Biodiversity" in Kohm, ed., ibid. at 227.

By October 1975, the U.S. Fish and Wildlife Service had received petitions to list almost 24,000 species under the U.S. ESA (W. Refalt, "The Endangered Species Lists: Chronicles of Extinction?" in Kohm, ed., ibid. at 81). Sixteen years later, only 1,000 had been listed and 3,000 more were in various stages of consideration (H. Salwasser, "In Search of an Ecosystem Approach to Endangered Species Conservation," in Kohm, ed., ibid. at 247).

D.D. Murphy, "Invertebrate Conservation" in Kohm, ed., ibid. at 195. 
about a species before it can be listed. Yet, it will be recalled that up to one half of Canadian species have not yet been classified at all. ${ }^{58}$ Thus, considering the backlog for listing and the number of unknown species, clearly extinction of far more species is threatened than will ever be listed. Fourth, even if there have been individual success stories under the America ESA, "most officially listed species are closer to extinction now than when they originally were listed."

Fifth, of the three levels of biodiversity listed earlier, the ESA approach appears to contribute mainly to species diversity, often through the saving of a fragment of one population. Genetic diversity of a species, however, requires a number of viable genetically differentiated populations. It also seems that ecosystem diversity may best be enhanced by focussing directly on it. As well, saving a remnant population will result in only a minimal contribution of the species to ecosystem maintenance functions. ${ }^{60}$

Since fragmentation and disappearance of habitat constitute the main threat to biodiversity, a necessary goal for conserving biodiversity would be to establish reserves of representative examples of the various habitat communities (usually identified by their dominant species) in an area. This "coarse filter" approach does not require detailed knowledge of individual species (although it cannot avoid singling some out), but assumes that viable populations of most resident species will thereby be saved. ${ }^{61}$ Management on this basis is cheaper and more broadly effective than implementing many species-specific recovery plans. Various considerations affect the choice of suitable areas, their size and their priority for selection. Depending on scale, the focal element could be a species or group of species, a distinct biological community (such as wetlands) or natural region (e.g., boreal forest).

Among the factors to consider when determining protected status are: species richness; whether the area is a critical habitat for threatened species, or is representative, unique or associated with important evolutionary processes; the requirements of migratory species; the degree of endemism (species uniqueness and nativism to the area); system sensitivity; the social, scientific or economic importance of resident species, and the amount of stress facing the area. ${ }^{62}$ The existence of "umbrella," "flagship" or "keystone" species may also be a criterion. ${ }^{63}$ Although the

Federal-Provincial-Territorial Biodiversity Working Group, supra note 7 at 9 . The number of undiscovered species can, presumably, be extrapolated from comparing the intensity of research efforts and past rates of discoveries. R. Noss, "From Endangered Species to Biodiversity" in Kohm, ed., supra note 43 at 228. A.H. Erlich \& P. Ehrlich, in Kohm, ed., ibid. at 298.

Hunter, supra note 54 at 266.

Federal-Provincial-Territorial Biodiversity Working Group, supra note 7 at 19-20.

See Noss, supra note 59 at 232-35. An umbrella species has large area requirements and hence its range would be large enough for many other species. A flagship species is a symbolic one, such as the "charismatic megavertebrates," including large carnivores. A keystone species is one whose role in the system is so fundamental that its disappearance will cause other dependent species also to disappear. An example is the red-cockade woodpecker, on whom some fourteen species of birds and mammals depend for their cavity nests. 
rarity of a species may also be relevant, since it can be a good predictor of vulnerability, it is often a poor indicator of ecological importance. Furthermore, in diverse communities, most species are relatively rare. ${ }^{64}$

Problems also exist with the coarse filter approach. For one, identifying relevant communities is not always simple, since often there are broad transition zones and considerable biological activity may occur along the boundaries. Therefore, somewhat larger scale areas may need to be chosen.

Another difficulty is that the coarse filter cannot be comprehensive. A third is that small-scale communities may be unable to support viable populations, especially if they are treated as islands whose surrounding areas are heavily altered by humans. This is especially relevant for wide-ranging, large carnivores, ${ }^{65}$ so that different scales may need to be considered. This issue also reveals a shortcoming of the reserve approach, unless it is supplemented with sensitive management for biodiversity in contiguous areas, whether they are in public or private ownership. A fourth limitation is that communities may be identified by a dominant species which is far more tolerant to a range of environmental conditions. If this is the case, it could be misleading to predict the presence of various other species. ${ }^{66}$ Since the mix of secondary species may differ within the area of one dominant species, depending, for example, on physical characteristics like climate, drainage, or soil, the coarse filter needs biophysical features to be entered into the equation. They may even be more important criteria than plant communities (and are often better documented).

These shortcomings of the coarse filter approach signal the need for a synthesis. Both coarse and fine filter methods are necessary. Coarse filter analysis must be supplemented with a "fine filter" for individual species identified as being under extreme threat, or for certain species with such limited habitat that generally representative communities may not include it. The need to include biophysical features in the coarse filter analysis, however, makes it clear that a more holistic perspective is required.

Noss believes that "indicator" species have been the poorest group to use for conservation decisions, partly because selection can be biased. A highly adaptive animal like the raccoon has been used, and species who thrive in edge conditions would not be reliable indicators for oldgrowth forests.

Ibid. at 236.

In Alberta's Kananaskis country, it has been estimated that an adult male grizzly's territory is almost 1200 square $\mathrm{km}$, although this can overlap with another male (Alberta Natural Resources Conservation Board, Decision Report Application \#9103 - Three Sisters Golf Resorts Inc. Application to Construct a Recreational and Tourism Project in the Town of Canmore, Alberta (November 1992) at 10-42). 


\section{The Ecosystem Approach}

Ecosystem management approaches are more rational, effective and efficient.

Developing and implementing an ecological approach to management with more emphasis on landscape level planning is imperative for effective conservation of biodiversity and the sustainable use of biological resources. ${ }^{67}$

Even the obligation of U.S. federal agencies under s. 7 of the American ESA to ensure that their actions are not likely to adversely modify endangered species' critical habitat does only part of the job, as is shown by continued deterioration of the situation. ${ }^{68}$

It must be acknowledged that the notion of ecosystem is an elastic classification concept. It might be used to describe a small area containing a rare species, or various increasingly broad areas within which smaller ecosystems nest. ${ }^{69}$ Presumably the ultimate ecosystem is the entire biosphere, although even it depends on or reacts to external inputs like solar radiation and the tidal effect from the gravitational forces of the moon and even the sun.

Two main classification systems of major natural regions have been used in Alberta, the "Natural Regions and Subregions" system and the "Ecoregions" system. Both were based on natural or biogeographic features and thus there was a strong overlap between them. Recently, the two have been combined into one common ecosystem classification system. ${ }^{70}$ It comprises grassland, parkland, foothills, Rocky Mountain, boreal forests and Canadian shield regions. (Conspicuous by their absence are inland waters and wetlands, although subregional classifications do acknowledge their existence as part of a complex.) To this are added twenty subregions. In turn, these may be broken down into four progressively more precise levels: ecodistricts; ecosections; ecosites; and ecoelements. ${ }^{71}$

This broader ecosystem approach can assist greatly in selecting reserve areas.

The main point is that an ecosystem provides a meaningful context for addressing genetic variation, viability of species populations, continued existence of biological communities, and richness of ecological processes.

... [I]t differs from traditional approaches to land and resource management ... in that it incorporates a wider breadth of ecological and social concerns as well as a longer time scale for productivity and renewability. ${ }^{72}$

Federal-Provincial-Territorial Biodiversity Working Group, supra note 7 at 36.

Noss, supra note 59 at 229.

Natural Resources Canada, supra note 12 at 25.

Alberta Environmental Protection, Natural Regions of Alberta (Edmonton: Alberta Environmental Protection, 1994) at 1.

Ibid. at 2.

72 Salwasser, supra note 56 at 251-52. See also Smith et al., supra note 45 at 1069-74. 
It is important to realize that existing ecosystems represent a snapshot of a continuing evolutionary process. To preserve biodiversity, our plans must allow for future rapid change. Humans may affect the earth's climate enough to change habitat conditions an order of magnitude more quickly than earlier natural perturbations. In fact, the present rate of global warming is about forty times faster than at the end of the last ice age. ${ }^{73}$ Even in the natural world, various mixes of species have changed over thousands of years, let alone the century or two contemplated today. For example, beech and hemlock, currently co-dominants in northern hardwood forests, had divergent ranges 12,000 years ago. ${ }^{74}$

Thus, we would be wise to establish reserve boundaries which can accommodate possible shifts in range of those communities which we wish to preserve. Another possibility is to impose reserve types of constraints on all land, private or public.

\section{Reserve Areas in Canada}

At present, about 910,000 square kilometres, roughly 9 percent of Canada, seem to have been protected to some degree; "about $4 \%$ is strictly protected from all commercial extractive activities." 75 Such estimates, however, may ignore the representivity or importance of the selected areas, since much of the provincial park system in Canada appears to have been designated for recreational purposes, with political and not ecological benefits in mind. Furthermore, it will be noted that certain resource exploitation is permitted on a significant portion of this land.

In Alberta, about 10 percent of the land area $(6,700,158$ hectares) is protected, with the lion's share being the three major National Parks of Banff, Jasper and, by far the largest, Wood Buffalo, together totalling 5.8 million hectares. ${ }^{76}$ Another way of looking at this is that the Province of Alberta has reserved only 1.9 percent of its land area (as well, another 2.4 percent enjoys protective zoning, mostly on the Eastern Slopes). Arguably it has a deliberate strategy to leave conservation efforts to federal initiatives instead of reserving its own land. At present, certain ecoregions are disproportionately protected, while others have no protection at all."

National parks, with a few exceptions, do not allow logging, mining or sport hunting. Recently, the Federal government has conceded that continuing commercial logging in Wood Buffalo National Park would be illegal. ${ }^{78}$ The same restrictions do not generally

S. Herrero, pers. comm., Jan. 10, 1995.
See Canadian Parks and Wilderness Society v. Wood Buffalo National Park (1992), 55 Fed.

78 S. Herrero, pers. comm., Jan. 10, 1995.
See Canadian Parks and Wilderness Society v. Wood Buffalo National Park (1992), 55 Fed. Rep. 286.

Life, supra note 6 at 152 .

Hunter, supra note 54 at 272.

Federal-Provincial-Territorial Biodiversity Working Group, supra note 7 at 19. Private charitable foundations have, however, also been active in acquiring privately owned habitat: the Nature Conservancy of Canada, for example, has created 505 nature preserves totalling 444,608 hectares (Nature Conservancy of Canada, 1993 Annual Report).

Alberta Parks Services, Designated Protected Areas (Special Places 2000 Category) (unpublished, 1994). 
apply in large provincial parks, although provincial wilderness areas and ecological reserves generally do not allow logging, mining or sport hunting. Many wildlife areas and migratory bird sanctuaries allow hunting and "commercial resource utilization." In Alberta, oil and gas wells exist in seven provincial parks, three ecological reserves and twenty-two natural areas. ${ }^{79}$ Further, some of these areas were not protected with biodiversity in mind. For example, "approximately one half of Alberta's provincial parks and natural areas ... have little protection value...." ${ }^{80}$

All told, national parks are the most protected areas in Canada. They account for over 70 percent of Canada's protected lands, if areas that allow logging, mining and dams are excluded from the calculation. ${ }^{81}$ According to Elgie, ${ }^{82}$ the percentage breakdown of protected areas is national parks, 27 percent; national wildlife areas and migratory bird sanctuaries, 18 percent; ecological reserves and wilderness areas 0.2 percent; ${ }^{83}$ provincial parks and wildlife areas, 54.8 percent. Since national parks constitute only 1.8 percent of Canada, Elgie's overall estimate of protected area in 1993 (which works out to 6.6 percent) is considerably lower than the figures cited in my other sources. More recent designations such as Clayoquot Sound, the Kitlope Drainage and the Tatshenshini in B.C. may account for much of this discrepancy.

About 12 percent of our forest land is protected, whether by policy or legislation, from harvesting. ${ }^{84}$ About 44 percent of this area is protected legislatively, 56 percent by policy. ${ }^{85}$ Not all of the country's ecological regions or critical wildlife habitat, however, have yet been protected. ${ }^{86}$ Although there has been a commitment by Canadian governments to increase the protected areas network to 12 percent of the country, ${ }^{87}$ significant new areas would have to be preserved in the three endangered species "hot spots" (southern B.C., the southern prairies and the Windsor-Quebec City corridor $^{88}$ ) to ensure viable populations of all vulnerable species. In these areas, however, the necessary land is not available, ${ }^{89}$ being held in private ownership, or else there is insufficient political support to acquire and set aside the necessary large tracts of land. For example, over 95 percent of the remaining remnants of Carolinian forest

Alberta Environmental Protection, supra note 70. "Fact Sheet - Special Places 2000: Alberta's Natural Heritage," accompanying News Release, March 28, 1995.

Alberta Environmental Protection, ibid.

S. Elgie, "Protected Spaces and Endangered Species," c. 10 in E. L. Hughes el al., Environmental Law and Policy (Toronto: Emond Montgomery, 1993) at 451.

Ibid.

Ibid. at 453.

Natural Resources Canada, supra note 12 at 4. The Canadian Forest Service estimates that about 22.8 million hectares of this area are highly protected and, by law, no timber harvesting is allowed there (Min. of Nat. Res., pers. comm., supra note 17).

Natural Resources Canada, ibid. at 9.

Federal-Provincial-Territorial Biodiversity Working Group, supra note 7 at 19.

Government of Canada, Canada's Green Plan (1990) at 80; Natural Resources Canada, supra note 12 at 64. Recent thinking stresses the need to complete the protective network of representative natural regions, without being limited by a 12 percent target (Min. of Nat. Res., pers. comm., supra note 17).

See text accompanying note 22 .

Federal-Provincial-Territorial Biodiversity Working Group, supra note 7 at 19. 
in Ontario is privately owned and only 1 percent is in national or provincial parks. Sixteen endangered species live in this forest. ${ }^{90}$

\section{BIODIVERSITY MANAGEMENT OF ALL LAND IS NECESSARY}

In a world of increasingly dense human population and an international determination to raise the physical standard of living of billions of people, it is inconceivable that biodiversity can be maintained by reserving from human use sufficient natural areas, untrammelled by humanity. We have come too far to achieve the "sustainable wilderness ideal of an unbroken wilderness matrix containing tiny human settlements," 11 attractive as such a notion may be. Thus, it is a "simplistic notion"92 that sufficient parks, nature preserves and ecological refuges can "protect more than a small fraction of the currently recognized endangered species...." 93 "Realistically, we cannot hope to conserve biodiversity just by protecting $12 \%$ of our natural areas. ${ }^{194}$ An "Eco-Blanket" approach is needed:

all parts of the landscape, increasingly also urban and other heavily developed areas, should be assigned a defined function in the service of biodiversity conservation. ${ }^{95}$

Furthermore, the preserve approach may imply that humans are interlopers in ecosystems, not an integral part of nature. Not only deep ecologists but increasing numbers of mainstream Canadians reject this approach. We are biological creatures, who, like all our fellows, cannot survive without healthily functioning ecosystems. Our challenge, as self-conscious beings, is to live healthy, sustainable lifestyles within (the limits of) natural biological systems.

These thoughts suggest a mixed conservation strategy involving reserves, buffer zones, multiple use management zones with pre-eminence given to sustaining natural ecosystems (e.g., old growth forests), more carefully managed sustainable harvesting of various living resources (e.g., on farms, in plantation wood lots and fisheries) and human settlements specifically designed and managed to maximize diverse habitat. Within the range of these possibilities is that of the creation of parks containing privately owned property, as exist in the U.S. and Britain, with conservation easements or other legal constraints on the type or intensity of economic activity or areas to be left in their natural state.

Natural Resources Canada, supra note 12 at 25.

G. Parton, "Sustainable Wildemess" (1994) 11 The Trumpeter 110.

Salwasser, supra note 56 at 248.

lbid.

Natural Resources Canada, supra note 12 at 31 . Mosquin et al., supra note 18 at 131-33, propose that one-third of the area of the Earth's natural ecosystems (representing the various eco-regions) be preserved in wild form, one-third be partially developed but sustainably managed and only one-third be devoted to intensive development.

C. Imboden, "Threatened Species: Birds as Indicators of Unsustainability" in Benneth, ed., supra note 2. 
Perhaps some brief elaboration of these non-reserve possibilities would help here, given the chequered history of multiple use policies, which have often camouflaged maximum industrial commodity production in once natural areas. ${ }^{96}$

Since reserves cannot succeed as mere islands in an industrially developed landscape, buffer zones of various sorts will be needed. For example, substantial wildlife migration corridors would allow seasonal migration, communication between populations and wide-ranging animals such as large carnivores to survive where reserved land was insufficient.

Buffer zones could also include some modest settlement and economic activity, so long as it was compatible with preservation of unfragmented habitat. Road access would, however, be limited, as it opens up country for various other uses whose combined impact could be unacceptable.

The so-called "biosphere reserves" seem to involve this sort of coexistence between natural systems and the earning of a sustainable living. (They may involve privately owned property and somewhat more intensive development, including ecologically sensitive farming, than just described.)

Multiple use zones could be the next more intensive belt. Careful ecological planning would precede such designation and regulators would have to ensure that no one "use" implied exclusion of other less intensive ones. Low impact techniques would again be essential for resource development and environmental/sustainability assessment should ensure that significant risk of ecological damage would constitute grounds for refusal of any proposed activity. There would be no possibility of assessments which excluded holistic consideration of systemic impacts. ${ }^{97}$

Intensively exploited lands would include farms, wood plantations which would be regularly cropped and areas deemed appropriate for major mining and hydrocarbon operations. Again, however, care would have to be taken to minimize ecological impacts and to manage the area actively with conservation in mind.

Finally, existing and new human settlements could be designed to use land more efficiently, with fewer ecological impacts and with careful design for habitat preservation or creation.

The import of this discussion is that significant new efforts will be needed to influence private land owners to manage their land so as to enhance biodiversity. More will be said later about this.

See e.g. M.C. Blumm, "Public Choice Theory and the Public Lands: Why Multiple Use Failed" (1994) 18 Harv. Env. L. Rev. 405.

The assessment of the proposed Alberta Pacific mill in 1989 excluded the environmental impacts of the forest harvesting necessary to feed the mill (except for that on Indian reserve land)! These issues were to be dealt with through the Alberta Department of Forestry. See Alberta-Pacific Environmental Impact Assessment Review Board, The Proposed Alberta Pacific Pulp Mill: Report of the EIA Review Board (Mar., 1990), Appendix A. 


\section{GENERAL ENVIRONMENTAL POLICY}

A related set of policies would also be necessary if we are to maintain biological diversity. Energy use patterns could be made far more efficient and less dependent on nonrenewable fuels, especially those high in carbon content. This would improve air quality and decrease the production of global warming gases. Because global warming could shift temperatures more quickly than vegetation can migrate, conservationoriented management of all land is absolutely essential if major losses of biodiversity are to be avoided.

Minimizing global temperature change is not the only wide-spectrum policy required. Requirements of "virtual zero" or non-measurable levels of toxic emissions to the environment would also reduce the stress on all species. Other policies, including agricultural, tax and transportation policy would need to be examined to remove inadvertent deterrents to achieving biodiversity. Indeed, tax and other economic incentives could provide an impetus to people to undertake preservation activities on privately owned land..$^{98}$ This is important, as agricultural activity on private land has probably had the greatest impact on the diversity of wildlife in Canada, through the elimination of habitat. ${ }^{99}$

Local support and involvement can also be enhanced by more programs like the federal Environmental Citizenship Initiative or other grants for environmental and conservation projects. Through such voluntary activities and formal involvement of the education sector, public understanding and professional knowledge about biological diversity could be much improved.

Because of the magnitude and urgency of the problem, however, there is no substitute for governmental initiatives at municipal, provincial, federal and international levels. Market sector actors rarely act primarily for the good-of-all-of-us, for the community's well-being. The invisible hand which supposedly brings about this result is, unhappily, at our throat.

\section{PRESENT LAWS IN ALBERTA}

Laws may affect an issue like biodiversity in various ways. They may have been passed specifically with the subject matter in mind, on a spectrum from symbolic reassurance of the public to highly detailed regulation. Or, statutes of a general nature may have wording broad enough to justify a concerned minister to come to grips with the issue. Perhaps more probably, in jurisdictions where primary resource exploitation has been a way of life, administration of development-oriented statutes may involve

See A.J. Kwasniak, Private Conservancy: the Path to Law Reform (Edmonton: Environmental Law Centre, 1994).

9

R.D. Sopuck, Canada's Agricultural and Trade Policies: Implications for Rural Renewal and Biodiversity (Ottawa: National Round Table on the Environment and the Economy, 1993) at 14, citing Environment Canada, State of Canada's Environment (Ottawa: Government of Canada, 1991). 
results adverse to environmental interests. It is easy to think of examples of this latter situation in Alberta's laws concerning agriculture, forestry and mineral development.

The following discussion of Alberta's policies and laws relevant to biodiversity will make it clear that considerable work could be, and is being, done within the present legal and policy framework. ${ }^{100}$

However, the government's approach to biodiversity issues is still evolving and significant gaps remain, particularly with regard to the reduction of biodiversity on privately held land. Even legislation specifically dealing with aspects of biodiversity allows exceptions, or could be improved.

It is proposed to summarize the Alberta situation in the following order. First, pursuing our focus on ecosystemic approaches to enhancing biodiversity, preservation statutes like the Provincial Parks Act, the Wilderness Areas, Ecological Reserves and Natural Areas Act and the Willmore Wilderness Park Act will be examined. Land use planning legislation will then be considered. Next, the Environmental Protection and Enhancement Act will be discussed, together with the project approval process as it has operated under the Natural Resources Conservation Board (NRCB) and the former Energy Resources Conservation Board (ERCB). ${ }^{101}$ Laws on public lands, wetlands and water resources will follow. Certain legislation concerning wildlife will then be summarized. Next, legislation concerning the agricultural, forest and mineral sectors will be described. Although biodiversity is not a major concern in these statutes, they have grave implications for it. Finally, miscellaneous legislative provisions will be mentioned.

\section{A. PROTECTED AREAS LEGISLATION}

The new Government Organization Act ${ }^{102}$ authorizes the Lieutenant-Governor-inCouncil to establish "Restricted Development Areas" or "Water Conservation Areas" for various relevant purposes when the Minister reports such is necessary in the public interest. ${ }^{103}$ The purposes include preventing the destruction of any natural resources (defined as "land, plant life, animal life, water and air"104), protecting a watershed, preserving natural areas "for the propagation of plant or animal life," and preventing environmental deterioration. Accompanying regulations may control, restrict or prohibit any uses or development of any land, or authorize the purchase or expropriation of any

Regional or Alberta conservation programs include the Prairie Conservation Action Plan, the Landowner Habitat Program, the Natural Areas Volunteer Steward Program and the putative Special Places 2000 Program (Public Advisory Committee, supra note 5 at 23-24). Under the Alberta Energy and Utilities Board Act, S.A. 1994, c. A-19.5, the ERCB has been combined with the Public Utilities Board to form the new Alberta Energy and Utilities Board (AEUB). Environment Act, s. 16.

Ibid.

104 Ibid., s. 1(c). 
interest of land, in the area. Watershed protection can also be effected by regulation without the creation of these areas. ${ }^{105}$

Thirteen Restricted Development Areas ${ }^{106}$ have been created (some have been abolished), but no Water Conservation Area has been established. ${ }^{107}$ Generally, the regulations provide that all powers under any Acts need the Minister of the Environment's approval before they are exercised, as does any action likely to result in surface disturbance. Most of the regulations restrict approvals to uses compatible with the purposes for which the Areas may be declared. Biodiversity considerations have been considered in dealing with the environmentally sensitive parts of three of these Areas, although it is intended to de-regulate these Areas on the theory that municipal land use planning controls are adequate. ${ }^{108}$

The Provincial Parks $A c t^{109}$ provides that Alberta parks

shall be developed and maintained

(a) for the conservation and management of flora and fauna,

(b) for the preservation of specified areas and objects therein that are of geological, cultural, ecological or other scientific interest, and

(c) to facilitate their use and enjoyment for outdoor recreation.

The ambivalence about the purpose of Canadian parks - conservation versus recreation - clearly emerges here. Some of the most contentious issues in Canada have resulted from disagreement about which goal is preeminent. Although Alberta's purpose section specifies that all three goals are to be achieved (implying that no trade-offs among them are acceptable), it gives less scope for environmentalists' legal arguments than other parks legislation in Canada (although controversy rages in these other jurisdictions as well). For example, national parks are to be maintained "unimpaired for the enjoyment of future generations," but Banff keeps growing and major expansion of the Sunshine ski area is underway again. Ontario parks are

dedicated to the people of Ontario ... for their healthful enjoyment and education, and ... shall be maintained for the benefit of future generations. ${ }^{110}$

Ibid., s. 8(a).

Hon. Ty Lund, Minister of Environmental Protection, pers. comm., Apr. 6, 1995. See Blue Ridge Alta. Reg. 340/74 (rep. 246/87); Calgary Alta. Reg. 212/76; Capital City Recreation Park Alta. Reg. 9/78; Edmonton Alta. Reg. 287/74; Edmonton-Devon Alta. Reg. 286/74; EdmontonFort Saskatchewan Alta. Reg. 285/74; Fish Creek Alta. Reg. 63/73 (rep. 85/92); Ft. McMurray Settlement Alta. Reg. 187/74 (rep. Alta. Reg. 8/95); Lethbridge Alta. Reg. $359 / 77$ (rep. 399/86); Pinehurst Lake Alta. Reg. 86/74 (rep. 1987); Sherwood Park West Alta. Reg. 45/74; Strathcona Alta. Reg. 158/76 (rep. Alta. Reg. 9/95); Turtle Mountain Alta. Reg. 225/76 (rep. Alta. Reg. 10/95), as am.

D. Percy, Wetlands and the Law in the Prairie Provinces of Canada (Edmonton: Environmental Law Centre (Alberta) Society, 1993) at 87.

Hon. Ty Lund, Minister of Environmental Protection, pers. comm., Mar. 2, 1995. The three RDA's were Calgary, Edmonton-Devon and Edmonton-Ft. Saskatchewan.

R.S.A. 1980 , c. P-22, s. 3.

R.S.O. 1990 , c. P-34, s. 2. 
Public trust arguments by a citizen aggrieved by a development decision in a park could be made under the federal and Ontario sections. Although no such arguments have yet succeeded to my knowledge, ${ }^{111}$ it is almost inconceivable that the Alberta wording could ever be relied upon in such a case.

It may be a different matter, however, when a disposition of park land is made for some use, such as resource extraction, which in some circumstances would be incompatible with both the preservation and recreation purposes. Possibly, an administrative law challenge, using Minister of Agriculture v. Padfield, ${ }^{112}$ to any decision which subverted the purposes of the Act, could succeed. In these circumstances, the court would not have to deal with the inherent conflict between the equally ranked conservation and recreation purposes. Although no direct provision is made in the Alberta Provincial Parks Act for resource extraction, authority exists for regulations to be made authorizing the Minister (of Environmental Protection) to make dispositions of interests or rights in public land under her administration. ${ }^{113}$ As well, the Minister can make regulations governing uses and activities, including "commercial activities," ${ }^{114}$ one of which could be resource exploitation. ${ }^{115}$

The Dispositions Regulation ${ }^{116}$ promulgated under the Provincial Parks Act appears to offer some protection for biodiversity by prohibiting the committing of waste and of any act which may endanger forest growth, injure watersheds or the bed of any body of water, or "the pollution of land, plant life, animal life, water or air." ${ }^{17}$ Notwithstanding this, however, the regulation specifically refers to the following kinds of dispositions: mineral surface, cultivation, hay, grazing, summer cabins, pipelines and as amended in 1981, sand, gravel, clay and marl and utility. ${ }^{118}$

Given the purpose section in the Provincial Parks Act, a Padfield-type challenge to the vires of some of these provisions might be plausible.

Another possible shortcoming in the Act is that parks and their boundaries are created by order of the Lieutenant-Governor-in-Council, ${ }^{119}$ not by legislation. Thus,

Although the Canadian Parks and Wilderness Society alleged breach of trust when suing for a declaration that logging carried out in Wood Buffalo National Park was illegal, the consent judgment to that effect, approved by MacKay J., was on the basis that the logging agreement approved by the Governor in Council was ultra vires because neither the National Parks Act nor regulations thereunder authorized commercial logging. See Canadian Parks and Wilderness Society v. Wood Buffalo National Park, supra note 78. Some recent fisheries cases may, however, presage further development of the doctrine in Canada (Nigel Bankes, pers. comm., Nov. 1994).

II4 Ibid., s. 11(d), (e), (o).

IIs The position regarding commercial development seems similar to that in most provinces (see Elgie, supra note 81 at 457 ).

Ibid., s. 8.

Alta. Reg. 372/81.

Supra note 109 , s. 7(1). 
their integrity could be seen as more threatened, even if they can be created more easily. (Section 6 permits the same authority to order purchase, expropriation or other acquisition of land for parks.) On the other hand, the Minister's power ${ }^{120}$ to declare by regulation any land under her administration subject to this $A c t$ or the regulations, as if it were a park, permits even easier creation of quasi-parks. (Ministers authorized by statute to create regulations do not require cabinet or Lieutenant-Governor-inCouncil approval for them.)

Habitat protection could be achieved under s. 13(1): by order of the Minister, all or any part of a park or recreational area ${ }^{121}$ may be closed for any periods deemed necessary. Also, areas may be zoned to "regulate or confine the various uses of land resources and water...."122

The preamble to the Wilderness Areas, Ecological Reserves and Natural Areas $A c t^{123}$ acknowledges that "progressively fewer areas" will be left in their natural state due to "continuing expansion of industrial development and settlement." Certain lands, totalling 389.92 square miles (1010 square kilometres) and described in the Schedule to the $A c t,{ }^{124}$ are established as wilderness areas, the most highly protected classification. There, the following activities are forbidden: hunting, fishing, trapping, vehicular travel, landing of aircraft, use of horses or pack animals, depositing garbage except where designated, removal of plant or animal life (including bird eggs), or fossils etc. Any disturbance of the surface requires ministerial approval. ${ }^{125}$

Virtually any existing disposition of any interest (surface, timber, mine, petroleum or natural gas) in a wilderness area is to be "withdrawn, cancelled or otherwise terminated as soon as possible." ${ }^{126}$ Furthermore, no new dispositions are permitted. ${ }^{127}$ Thus, wilderness areas are protected quite rigorously. Unlike ecological reserves, however, lighting fires appears to be permissible.

Ecological reserves can be created, on public land, by the Lieutenant-Governor-inCouncil for any of the following reasons: suitability for scientific research concerning natural ecosystems; being a representative example of a natural ecosystem in Alberta, or a modified ecosystem whose recovery could be studied; containing rare or

Ibid., s. 7.1.

Eighty-seven recreational areas are described in Alta. Reg. 37/94. See also the Provincial Recreation Areas Regulation Alta. Reg. 213/92 as am. by Alta. Reg. 38/94, which describes another nine areas; and Alta. Reg. 263/94.

Supra note 109, s. 13(1)(d).

R.S.A. 1980 , c. W-8.

These are the Ghost River (59.14 square miles), Siffleur (159.13 square miles) and the White Goat Wilderness (171.65 square miles) Areas.

Supra note 123, s. 8(1)(e).

Ibid., s. 6(1).

Ibid., s. 7(1)(a). 
endangered plants or animals that should be preserved, or unique or rare examples of natural biological or physical features. ${ }^{128}$

The protection extended to ecological reserves is slightly less comprehensive than for wilderness areas. All activities proscribed in the latter are likewise prohibited in ecological reserves, except that the use of motorized vehicles or boats on designated routes or areas is allowed, as is the use of horses or pack animals throughout. No fires are allowed. ${ }^{129}$

Rules regarding dispositions of interests in ecological reserves are also less rigorous. Petroleum or natural gas dispositions, at the option of the Minister of Environmental Protection, ${ }^{130}$ may remain and existing dispositions of other kinds run until they expire. Also, with written permission of the Minister, they may be renewed. ${ }^{131}$ Furthermore, new dispositions under the Mines and Minerals Act are permitted. ${ }^{132}$

Travel in either type of area may be prohibited or regulated by permit. ${ }^{133}$

The Minister may carry out programs

(a) for the management and preservation of the animal and plant life and the environment of the wilderness area or ecological reserve,

(b) for environmental research that does not involve any physical disturbance ...,

(c) generally, for the preservation and protection of the wilderness area or ecological reserve. ${ }^{136}$

Controlled buffer zones on public land next to either kind of area may be created by regulation. There, no quarrying or strip mining may take place, nor may any diversion, undertaking or works under the Water Resources Act take place. ${ }^{135}$

Lastly, natural areas may be designated on public land by the Lieutenant-Governorin-Council, in order to

(a) protect sensitive or scenic public land from disturbance, and

(b) ensure the availability of public land in a natural state for ... recreation, education or any other purpose. ${ }^{136}$

Ibid., s. 3.1(1). As of May, 1990, there were eleven ecological reserves, averaging about 1900 hectares in size (Expert Panel, Forest Management in Alberta (Edmonton: University of Alberta, 1990) at 48). 
The only protection afforded this type of lands seems to be that timber dispositions or any dispositions under the Public Lands Act need the consent of the Minister of Forestry, Land and Wildlife. ${ }^{137}$ By implication, all other dispositions are possible through the normal process, although the Lieutenant-Governor-in-Council has the power to make regulations about the "management ... and utilization" of all types of areas which may exist under the Wilderness Areas, Ecological Reserves and Natural Areas Act. ${ }^{138}$ No such regulations, however, appear to exist.

It may be questioned whether natural areas, under these circumstances, should be seen as protected areas at all.

It should be noted that all these areas, including buffer zones, can be created only on public land and there is no provision in the Act for purchase or expropriation of private land whose designation might be desirable.

The brief Willmore Wilderness Park Act establishes a large area $(1,774.8$ square miles, 4598 square kilometres) as a wilderness park. ${ }^{139}$ Until it was amended in October, $1995,{ }^{140}$ it would have been cynical, but understandable, to conclude that the Act was a political ploy designed to offer symbolic but not actual support for environmental values. Although no disposition of any interest in land in the park could be made under any Act or regulation, the Lieutenant-Governor-in-Council was given virtually unlimited powers in the Act to provide otherwise by regulation or order. ${ }^{141}$ The area of the park may still be altered thereby. ${ }^{142}$ Thus, resource exploitation could proceed by fiat. The Act's sympathy for development was underlined by the provision that "the administration and control of mines and minerals" was not affected by the Act. ${ }^{143}$ Recall that the term "minerals" in the Mines and Minerals Act includes petroleum, oil, oil sands and natural gas. ${ }^{144}$

Thus, not much statutory protection was afforded this wilderness park, unless the dedication section helped:

The Park is dedicated to the use of the people of Alberta for their benefit, education and enjoyment, subject to this Act and the regulations, and shall, by the management, conservation and protection of its natural resources and by the preservation of its natural beauty, be maintained for the enjoyment of future generations. ${ }^{145}$

Wilderness Areas, Ecological Reserves and Natural Areas Act, ibid., s. 12.1(3).

Ibid., s. 14(1).

R.S.A. 1980, c. W-10.

Bill 43, Willmore Wilderness Park Amendment Act, 1995, 3d sess., 23d Leg., Alberta, 1995, (3d reading 19 October 1995).

lbid., ss. 4, 5, 7, 8. Fortunately, these extensive powers were not exercised.

Ibid., s. 2(2).

Ibid., s. 6.

R.S.A. 1980 , c. M-15, s. 1(1)(m).

Supra note 139, s. 3 [emphasis added]. 
Could these words have been the basis for challenges, under the public trust and Padfield doctrines, to resource exploitation approvals? Arguably, only the dedication in the first eighteen words, the use by "the people," is "subject to ... the regulations." The obligation to manage, conserve and protect the natural resources and to preserve the natural beauty seems not to be modified by this "subject to" phrase, which would have covered the whole section had it been placed at the beginning.

Even if this reading is questionable, one could have argued that the powers given to the Lieutenant-Governor-in-Council to vary or make inapplicable the provisions of various other Acts or regulations were meant to ensure more, not less, rigorous protection of Willmore. These regulations, of course, had to be intra vires. The obligation to manage, conserve and protect the natural resources and to preserve the natural beauty arguably would have excluded regulations allowing any resource allocations which prevent the fulfillment of that duty.

There was a significant inconsistency in the Act. On the one hand, s. 3 opens the door for the argument just described. How can non-renewable natural resources be conserved and protected by exploitation? On the other hand, the Act specifically abstained from affecting "the administration and control of mines and minerals within ... the Park," ${ }^{146}$ the paradigm of non-renewable resource exploitation.

One would also have to deal with the authorization in the Act of "regulations prescribing methods of disposing of ... interests in land within the Park under any act or regulation which would apply to ... the Park but for this Act." ${ }^{147}$ Clearly, dispositions were contemplated by the Act.

Until recently, conservative courts would not be expected to strain language to uphold an environmental challenge. The Supreme Court of Canada, however, surprised many of us with its holding in Friends of the Oldman River Society v. Her Majesty the Queen in right of Canada, the Ministers of Transport and of Fisheries and Oceans. ${ }^{148}$ There, the Court ignored the adjective "natural" in front of "environment" in s. 4(1)(a) of the federal Department of the Environment $A c t^{149}$ when it held that "environmental quality" in s. 6, whose meaning is parasitic upon s. 4, authorized the EARP Guidelines $\operatorname{Order}^{150}$ to require socio-economic assessment. We may therefore assume that some courts are prepared to overcome technical interpretive problems if they think the public interest requires it.

What Alberta courts would have done here is anyone's guess. Fortunately for preservation, ss. 4-8 of the $A c t$ have just been repealed. The new ss. 4-5 unequivocally provide that no industrial activities, including mining, may be conducted in the park and that no dispositions, licences, permits or approvals for geophysical or geological

$\begin{array}{ll}146 & \text { Ibid., s. } 6 . \\ 147 & \text { Ibid., s. } 5 . \\ 148 & \text { [1992] S.C.R. 3. } \\ 149 & \text { R.S.C. } 1985 \text { c. E-10. } \\ \text { 150 } & \text { S.O.R./84-467. }\end{array}$


exploration or for water conservation or hydro-power may be issued. Furthermore, the Lieutenant Governor's authority to create regulations are subject to these provisions and (as before) to the purposes of the Act.

Since only 1.4 percent of Alberta's land area has so far been reserved by the province, the government's decision to implement the "Special Places 2000" proposal $^{151}$ is certainly timely. The original idea was that viably sized representative tracts of each Alberta ecoregion be identified and then reserved from development. The government has industry support for this: "a good land use policy is not set hearing by hearing, valley by valley."152 Unhappily, it seems that various resource development activities will be allowed to continue in some of these areas. ${ }^{153}$ This emphasis on economic development will significantly dilute the biodiversity benefits of the program, as well as removing the very certainty which industry sought.

As well, the shortcomings in existing reserve legislation, identified above, should be fixed. One effective way of doing this would be to enact one omnibus reserves Act.

\section{B. PLANNING LEGISLATION}

Recently, the former Planning Act was replaced by new planning legislation, ${ }^{154}$ which is now Part 17 of the new Municipal Government Act. ${ }^{155}$ The twin stands of devolution of authority to municipalities and unleashing of market forces are evident in the new legislation. In addition, the realities of reduced provincial funding and the need for cost-effectiveness, inter alia, helped to motivate the new law, ${ }^{156}$ as, arguably, did the government's desire to respond to concerns of rural voters.

The October 1994 Proposals document ${ }^{157}$ which preceded the new legislation seemed to promise considerable improvement in the planning regime's treatment of environmental and biodiversity issues. For example, "the patterns of human settlement will be concentrated to ensure ... resource conservation, minimal impact on the

Public Advisory Committee, supra note 5. The Alberta Government is now moving to implement the program (The Calgary Herald (18 Jan. 1995) Dl), although first indications are that various resource development activities will be allowed to continue in such areas (The Calgary Herald (20 Mar. 1995) Al).

D. Bruchet, representing the Canadian Association of Petroleum Producers (The Calgary Herald, ibid.).

The Calgary Herald (20 Mar. 1995) Al. A Herald Editorial on 31 Mar. 1995 called the government approach "an economic development program with a conservation component." Municipal Government Amendment Act, 1995, S.A. 1995, c. 24, (assented to 17 May 1995) [hereinatter the MGAA]. The MGAA repealed the Planning Act, R.S.A. 1980, c. P-9.

S.A. 1995, c. M-26.1. All references to the new sections will be to the numbers as they appear in the Municipal Government Act, not to the section numbers in the MGAA which enacted them.

A lengthy list of factors contributing to the review of the old Act appears in Alberta Municipal Affairs, Alberta Planning Act - Review '94 Discussion Paper (Edmonton: Alberta Municipal Affairs, March 1994) at 2.

157 Alberta Municipal Affairs, Alberta Planning Act - Review '94 Proposals (Edmonton: Alberta Municipal Affairs, October 1994) [hereinafter Proposals]. 
environment....158 As well, "municipalities may request environmental information assessing the impacts of development and identifying appropriate mitigative measures." ${ }^{159}$ Lastly,

[m]unicipalities should encourage human settlement in such a manner that the integrity of significant ground water recharge areas, wildlife habitats, unique environmental features and significant wetlands are maintained.... ${ }^{160}$

Many of the items relevant to our purpose here, however, remained unchanged in the new Municipal Government Act.

It is first useful to note that one of the purposes of the planning regime remains to "maintain and improve the quality of the physical environment within which patterns of human settlement are situated." ${ }^{161}$ This is consistent with the proposal herein that all land should be managed so as to preserve biological diversity, although unfortunately the $A c t$ 's thrust does not yet live up to this promise.

One might think that regional planning powers could be potentially effective instruments for maintaining biodiversity. Regional plans and regional planning commissions, however, have been abolished, ${ }^{162}$ in favour of various channels for voluntary intermunicipal planning. ${ }^{163}$ On the other hand, increased provincial supervision will be provided through new, binding provincial land use policies to be issued, by order of the Lieutenant-Governor-in-Council, on the recommendation of the Minister. ${ }^{164}$ The rigour of this requirement will depend on the statements' contents (none of which is specified in the Act). According to the Proposals, municipalities will be expected to encourage development "in such a manner that the integrity of ... wildlife habitats, unique environmental features and significant wetlands are maintained or enhanced within the limitations ... in the ... legislation." ${ }^{165}$

Another potentially useful provision of the former Planning Act involved the Lieutenant-Governor-in-Council's power to create special planning areas. One of the original reasons for this was to permit green belts to be established. ${ }^{166}$ Very extensive regulations concerning these areas could have been promulgated and they could override any existing land use plans or by-laws. ${ }^{167}$

Ibid. at 6.

Ibid. at 9.

Ibid.

Supra note 155, s. 617.

Ibid., s. 703.

E.g., a continuation of the possibility of intermunicipal planning commissions (ibid., s. 626), to adopt intermunicipal development plans (s. 631), regional services commissions with a broader mandate (s. 602.01) and the new intermunicipal service agencies (s. 625).

Ibid., s. 622.

Supra note 157 at 9.

See speech of Hon. Dick Johnston, then Minister of Municipal Affairs, Legislative Assembly, Alberta Hansard, Number 64 (21 October 1977).

Planning Act, supra note 154, s. 150. 
No such special planning areas presently exist and the new legislation does not authorize their creation.

Under the new legislation, prepared at the same time as the Special Places 2000 proposals, we might expect that sites of unusual biological diversity, or those containing rare or endangered species, could be required by subdivision authorities (now municipally based ${ }^{168}$ ) to be provided as environmental reserve. Unhappily, the same definition is provided as before, basing environmental reserve mainly on the physical safety of development. Biologically important sites qualify to be taken only if they are coincidentally in "a swamp, gully, ravine, coulee or natural drainage course," are subject to flooding, or constitute a strip of land abutting a body of water whose reservation is desirable for public access or to prevent pollution. ${ }^{169}$ No mention is made of ecological importance as a reason for reserving land. Habitat areas of the sort mentioned may therefore be protected, but a more likely outcome, in the case of land which can feasibly be drained, is that the authority to reserve it will not be exercised. This has become more likely since 1984, when the power to reserve "land ... unsuitable in its natural state for development" was repealed. ${ }^{170}$ The new legislation contemplates the possibility of easements or restrictive covenants being used as an alternative to the environmental reserve provisions. ${ }^{171}$

As before, the possibility exists of changing environmental reserve from its natural state or using it for other than a public park. Now it is a matter for council, after a public hearing. ${ }^{172}$ Also, the new option exists of transferring it to the Crown. ${ }^{173}$

The possibility still exists of building public roadways, public utilities, pipelines or transmission lines through reserve land, including environmental reserve, "if the interests of the public will not be adversely affected." ${ }^{174}$ Rigorous protection of environmental reserve, therefore, is somewhat lacking, as very few judges would consider substituting their view of the public interest for that of the council.

No instrument regarding subdivided land may be registered if its effect may be to subdivide the parcel. ${ }^{175}$ This provision could inhibit the purchase, for conservation purposes, of interests over part of a larger parcel which is otherwise devoted to a use such as farming.

The former Subdivision Regulation ${ }^{176}$ had a double-edged provision which was meant to preserve agricultural land from "country residential" acreage development. Subdivision was to be refused in rural municipalities unless the land had a low

Supra note 155, s. 623(1).

Ibid., s. 664(1).

Planning Act, supra note 154, s. 95(c) [emphasis added] was repealed by S.A. 1984, c. 33, s. 6. Supra note 155, s. 664(2).

Ibid., s. 676(1).

Ibid., s. 676(1)(b).

Ibid., s. 677.

Ibid., s. 652(1).

Alta. Reg. $132 / 78$ as. am. 
agricultural capability. ${ }^{177}$ This diverted sprawling, urban shadow development to land which, being less suitable for agriculture, was likely to have been left in a more or less natural state. Thus, when the land is converted, habitat is lost.

The intended new subdivision and development regulations ${ }^{178}$ omit any mention of preserving agricultural land, or of consideration of biological diversity when making subdivision or development decisions.

An opportunity was missed here. The regulation could have included criteria for refusing subdivision for reasons of biological diversity or other environmental grounds. Accompanying tax relief, or in extreme cases where economic use of the parcel was completely compromised, financial recompense, could also have been considered. ${ }^{179}$

Lastly, the municipal development plan "may address environmental matters within the municipality" and "may contain statements regarding ... development constraints, including the results of ... impact analysis." ${ }^{180}$ But the land use bylaw is the place where specific power to regulate would sit most comfortably. The inference of regulatory power from the plan's ability to address environmental matters is rather tangential. Given the apparent commitment to greater consideration of environmental and biodiversity factors in land use planning, it seems bizarre that the Act confers no new authority for municipalities to require applicants to prepare environmental assessments or to consider biological diversity matters in the subdivision and development process.

We must depend on the same limited wording as before, wording which provides at least limited authority for environmental factors to be included in land use decisions. The land use bylaw may provide for the development of buildings "on land subject to flooding or subsidence or that is low lying, marshy or unstable" or on land within a specified distance of body of water. ${ }^{181}$ These provisions, although partly oriented to safety, offer support for preserving some significant habitat land. Arguably as well, environmental conditions in permits would be justified under s. 640(2)(c)'s authority to

establish a method of making decisions on applications ... including provision for (iv) the conditions that ... the development authority may attach ... to a development permit....

Also, the power to provide for "any other matters necessary to regulate and control the issue of development permits"182 might justify requiring EIA's and acting upon their information.

Alberta Municipal Affairs, A Discussion Paper on the Proposed Subdivision and Development Regulation (Edmonton: Alberta Municipal Affairs, 1995).

179 As is well known, S. 4 of the old Planning Act (s. 621(1) in the new legislation) specifies that nothing in the Act, regulations, plans or land use bylaw gives any right to compensation.

Ibid., s. 640(4)(1).

Ibid., s. 640(2)(c)(vii). 
It must also be recalled that the direct control provisions of the Act would enable detailed habitat preservation planning:

If a direct control district is designated ... the council may, subject to any applicable statutory plan, regulate and control the use or development of land ... in any manner it considers necessary. ${ }^{183}$

The problem is that, under all this wording, many municipalities under the old $A c t$ either were not too concerned about this kind of question, or else took a conservative view of their powers in this regard, perhaps because of exaggerated fears of legal liability. Something should have been added to the Act to make it clear that municipalities are intended to consider this sort of issue.

Years ago, I was critical of the Act's failure to provide sufficient direction to municipalities to incorporate environmental considerations into their land use planning. ${ }^{184}$ This criticism can now be repeated with respect to biological diversity, although the new legislation could somewhat improve the situation.

Tkachuk suggests that the Special Areas $A c t^{185}$ might have positive and substantial effects if it were "directed toward the preservation of wetland habitat" (the focus of his work). ${ }^{186}$ Under the Act, the Lieutenant-Governor-in-Council may by order constitute special areas, whereupon the Minister of Municipal Affairs may classify lands within those areas so that they may be used most suitably. Further, orders may require occupants of land to employ necessary farming and grazing practices to prevent soil drifting, water erosion or over-grazing. Measures may also be taken to promote the development and conservation of all natural resources. ${ }^{187}$

Although these powers might offer some support for biological diversity, they are specifically oriented toward greater economic security and stability of income, goals which are not always compatible with biological conservation.

\section{EPEA, THE BOARDS AND THE APPROVAL PROCESS}

The omnibus Environmental Protection and Enhancement Act ${ }^{188}$ is Alberta's flagship environmental legislation. Proclaimed in force in September 1993, it replaced eight statutes ${ }^{189}$ and numerous new regulations were promulgated under it. Although biodiversity issues are not specifically addressed, a number of parts of the EPEA have direct implications for biodiversity.

\footnotetext{
183 Ibid., s. 641(2).

184 P.S. Elder, "The New Alberta Planning Act" (1979) 17 Alta L. Rev. 434, esp. 458 ff.

185 R.S.A. 1980 , c. S-20.

186 D.M. Tkachuk, Alberta's Wetlands: Legal Incentives and Obstacles to Their Conservation (Calgary: Canadian Institute of Resources Law, 1993) at 20.

187 Supra note 185 , s. 7.

188 S.A. 1992, c. E-13.3 [hereinafter EPEA].

189 Agricultural Chemicals Act, Beverage Container Act, Clean Air Act, Clean Water Act, Ground Water Development Act, Hazardous Chemicals Act, Land Surface Conservation and Reclamation Act and Litter Act.
} 


\section{EPEA's purpose}

is to support and promote the protection, enhancement, and wise use of the environment while recognizing the following:

(a) the protection of the environment is essential to the integrity of ecosystems ...;

(c) the principle of sustainable development ...;

(d) the importance of preventing and mitigating the environmental impact of development.... ${ }^{190}$

Under s. 22(1), the Minister could purchase conservation easements from landowners. (A similar but more general power, including authority to expropriate, is granted in the new Government Organization Act. ${ }^{191}$ ) These registrable agreements run with the land, without the need for government to own benefiting land (a dominant tenement). Thus, habitat protection seems to be contemplated, although no such agreements have yet been achieved. ${ }^{192}$

The Environmental Protection and Enhancement Fund is established under the $E P E A^{193}$ (its genesis and main function has been to deal with emergencies). ${ }^{194}$ This could be a major source of funds for environmental enhancement purposes, for revolving funds may be advanced by the Provincial Treasurer so long as the balance outstanding does not exceed $\$ 100$ million. As I read the fund's business plan, however, it seems that up to 90 percent of this amount is reserved for fire fighting and other types of emergencies. Forest resource enhancement will consume the rest. ${ }^{195}$

Various programs established under the EPEA imply considerable benefit for biodiversity. The approval process for new industrial activity, for the disposal of solid waste (including recycling), for the handling of hazardous products, pesticides, the drilling of water wells and water treatment facilities all offer some degree of protection to the natural environment. So do the Part 5 provisions for the reclamation of land (returning it to "an equivalent land capability," ${ }^{196}$ specified in the regulations, ${ }^{197}$ after it is disturbed in various non-agricultural or non-residential uses).

Perhaps the most significant development in the new EPEA is the enactment of a robust environmental impact assessment regime, formerly consisting of policies based on s. 8 of the old Land Surface Conservation and Reclamation Act. ${ }^{198}$ An understanding of Alberta's approach also requires reference to the mandates of the

Supra note 188 , s. 2.

Supra note 102, Schedule 5, s. 2(1), continuing the power given in the Department of the Environment Act, R.S.A. 1980, c. D-9, s. 9(1).

Hon. Ty Lund, Minister of Environmental Protection, pers. comm., Mar. 2, 1995.

Supra note 188, s. 28.

Vernon Albush, Executive Assistant to the Assistant Deputy Minister, Corporate Management, Alberta Environmental Protection, pers. comm., Mar. 10, 1995.

Budget projections submitted to Alberta Treasury by the Department of Environmental Protection, courtesy of Vemon Albush, ibid.

Alta. Reg. 115/93, s. 2.

Ibid., s. 1(w).

R.S.A. 1980 , c. L-3. 
NRCB and the ERCB. Although the latter board has been amalgamated with the Public Utilities Board and renamed the Alberta Energy and Utilities Board (AEUB), ${ }^{199}$ for ease of reference, the old board's name is used. The new board retains the former ERCB's powers.

The process applies to proposed activities (usually "construction, operation or reclamation"), listed in a schedule to the EPEA or so designated by regulation. Environmental impact assessment (EIA) reports must be prepared for mandatory activities designated by regulation, ${ }^{200}$ or if the designated Director of Alberta Environment so decides. This decision is based on legislated general considerations, including information required by regulation and anything the Director considers relevant. ${ }^{201}$ Among issues to be considered are the activity's location, size, nature, complexity, public concern and the presence of other similar activities in the general area. Apart from listing these considerations, no specific criteria are provided for the Director by the EPEA. Due consideration is to be given to expressions of concern by directly affected members of the public. ${ }^{202}$ Impacts on biodiversity are not mentioned, although clearly the Director could consider them as being relevant.

The EPEA also authorizes activities to be exempted by regulation from the EIA process. ${ }^{203}$ It is interesting that oil and gas wells are exempted, ${ }^{204}$ although the cumulative impacts (and ecosystem fragmentation) of more than two hundred thousand of them have been immense. ${ }^{205}$ The AEUB will have to assess the desirability of future wells without the benefit of formal EIA's under the EPEA.

If the Director decides that further assessment is required, a screening report, with contents specified by ministerial regulation, ${ }^{206}$ is to be prepared and made available through putting it in the registry. ${ }^{207}$ Notice of the decision to require an EIA report is similarly filed and distributed to persons who submitted a statement of concern. ${ }^{208}$

Supra note 101 .

Supra note 188, s. 57(a). Alta Reg. $111 / 93$ in many instances sets a threshold emission or production level below which assessment is not mandatory.

EPEA, ibid., s. 42(3).

Ibid., s. 44.

Ibid., s. 57(b).

Alta. Reg. 111/93, s. 2, Schedule 2.

The ERCB estimates an average wellsite to cover four acres. They are, however, usually reclaimed upon abandonment (Resource Planning Branch, Alberta Agriculture Food and Rural Development, Agricultural Land Base Monitoring Study (1986-1990) (Edmonton: Alberta Agriculture, 1993) at 7).

Supra note 188, s. 56 refers to regulations "respecting the preparation of screening reports." This power, however, apparently differs from that given in the section to make regulations "respecting the form and content of" EIA reports, wording which would more clearly have grounded the type of directions for screening reports contained in Alta. Reg. 111/93, s. 4(1).

EPEA, ibid., s. 43(1) and Alta. Reg. 111/93, ibid., s. 4(2).

EPEA, ibid., s. 5. 
The Minister may intervene in the process described above and direct the proponent to prepare an EIA report, even if the activity has been exempted by regulation. ${ }^{209}$ It should also be noted that ministerial intervention in the approval process may kill a proposal by ordering that no approvals be issued under the EPEA. ${ }^{210}$ Thus, an aggressive minister has an environmental veto, which could be exercised because of biodiversity concerns.

If no EIA report is required, the proponent proceeds to apply for the necessary approvals. If an EIA report is required, the proponent submits to the Director and publicizes proposed terms of reference. After receiving and considering public comment, the Director issues the final terms of reference. ${ }^{211}$ The EIA report is then prepared and published ${ }^{212}$ by the proponent and must contain information listed in the $E P E A$ unless the Director decides otherwise. ${ }^{213}$ Ten items are listed, including description of and analysis of the need for the proposed activity; site selection process and alternative sites considered; alternatives to the activity; including a "no go"; existing baseline environmental conditions; potential positive and negative environmental, socio-economic and cultural impacts, including cumulative and regional considerations; mitigation; contingency; and monitoring plans. ${ }^{214}$

After considering the report and any additional information required, the Director may decide the report is complete (no criteria are provided to guide this decision) and so notify the Chairs of the NRCB or the ERCB, if the project requires either board's approval or review. In all other cases, the Director submits the report, together with any further information or recommendations considered appropriate, to the Minister. ${ }^{215}$ The Minister may then advise the proponent that the necessary approvals may be sought, or may request the Lieutenant-Governor-in-Council to refer the proposed activity to the NRCB for review. ${ }^{216}$ Finally, the Minister may order that no approvals be issued, as mentioned a moment ago. It is an offence for anyone without an approval to commence or continue any activity which requires one. ${ }^{217}$

Provision is made for cooperation with like processes of other jurisdictions. ${ }^{218}$

Directors considering applications for approvals under the EPEA must consider applicable decisions of the NRCB or ERCB and may consider the evidence put before them. ${ }^{219}$ There seems to be no corresponding duty, however, to consider the contents of an EIA report which does not go to either Board. 
Although provisions are made by the $E P E A$ for public notification and submissions in the EIA process, only activities within the purview of the NRCB or ERCB are intended to undergo public hearings. The general position concerning the control of pollution and ensuring of environment conservation in energy-related activities can be briefly sketched out.

Permission of the ERCB is required before most energy activities (reviewable coal, hydro-electric, oil, oil sands and natural gas projects) are undertaken. In addition to the more technically oriented provisions in various Acts, the Board is to

give consideration to whether the project is in the public interest, having regard to the social and economic effects of the project and the effects of the project on the environment. 230

For present purposes, it should be noted that approvals by the Board may be subject to conditions relating to the mitigation of potential adverse effects. In this regard, biodiversity or habitat issues have been recognized by the Board. (It should be noted that the Ministers responsible for Environmental Protection and the Public Lands Act (presently the same person) may, where applicable, impose conditions on approvals otherwise acceptable to the Board. ${ }^{221}$ ) For instance, although the Whitney Creek well application, in an area zoned as multi-use under the Eastern Slopes Policy and also designated by UNESCO's Man and the Biosphere program as a biosphere reserve, was approved by the ERCB, ${ }^{222}$ the decision specifically stated that unacceptable environmental impacts could be sufficient grounds for refusal of an application. ${ }^{223}$

An interesting development followed the Whitney Creek approval. The Board observed that intervenors' concerns in this and previous individual well applications

Energy Resources Conservation Act, R.S.A. 1980, c. E-11, s. 2.1.

Coal Conservation Act, R.S.A. 1980, c. C-14 ss. 21(2), 24 (Minister of Environmental Protection alone); Hydro and Electric Energy Act, R.S.A. 1980, c. H-13, s. 7(4), 7(5) (both ministers); Oil and Gas Conservation Act, R.S.A. 1980, c. O-5, ss. 14.1(3) (road location on public lands needs approval of the Minister responsible for the Public Lands Act), 26(2)-(4) (Minister of the Environment alone); Oil Sands Conservation Act, S.A. 1983, c.0-5.5, ss. 19(2), 19(3), 19(6) (Public Lands); Pipeline Act, R.S.A. 1980, c. P-8, s. 8 (both ministers, although Hon. Ty Lund, Minister of Environmental Protection, appears to have exercised his power (in s. 8(3)) to direct that applications need not be referred to him (pers. comm., Mar. 2, 1995)). Under some of these sections, the Lieutenant-Governor-in-Council may make the ultimate decision and may choose not to include these conditions.

It should be noted that such applications first go through a leasing or licensing process under the Mines and Minerals Act, including approval of the disposition of this interest through the Crown Mineral Disposition Review Committee. In the Whitney Creek case, the Mineral Surface Lease was also granted pursuant to numerous environmentally related conditions.

Oil and gas activity is categorically excluded from the Prime Protection Zone of the Slopes. Indeed, when the Eastem Slopes policy was implemented, the Crown bought back about \$20 million worth of exploration rights in extremely ecologically sensitive areas, or in those having resources considered more valuable than the oil and gas. See G. Goodman, The Approval Process for Gas Wells in the Eastern Slopes of Alberta (Faculty of Environmental Design, University of Calgary, 1993) [unpublished Master's Degree Project] at 35-45.

ERCB, Application for a Well Licence Waterton Field Decision D 88-16 (22 December 1988) at 10. 
could have better been dealt with through ongoing consultation rather than through the hearing process. As a result, a non-profit society, the Crown of the Continent Society, was formed by interested people in the region. The Board and at least two major petroleum companies, Shell and Amoco, are members, as is the Canadian Parks and Wilderness Association. The Society's object is

to help ensure for future generations of all living things ... the Crown of the Continent, through a locally-based cooperative approach that strives to ensure the preservation, wise use and restoration of the natural environment and the well-being of area communities. ${ }^{224}$

Shell Canada has discussed with the Society its plans for a seven-well drilling program. ${ }^{225}$

A current example of the effect of the public's, and the ERCB's, increasing environmental awareness came in the Whaleback Ridge decision on an application by Amoco Canada for approval of an exploratory well in an undeveloped area north of the Oldman River and west of Highway $22 .{ }^{226}$ After this application, but before the hearing on it, the Board released a new, somewhat general, policy concerning the southern portion of the Eastern Slopes. ${ }^{227}$ This policy reflected "a shift of public values which has resulted in a greater emphasis by the public on the protection of wildlands and of ecological integrity" of the area. ${ }^{228}$ It notified companies of the need for thorough public consultation, a best estimate of the overall extent of development (not just detail on the specific well) and environmental assessments of each proposed development stage. These initiatives appear to reflect an increased awareness that single well proposals need to be assessed in the light of an overall land use planning perspective. Otherwise, incremental decisions might unwittingly foreclose preservation options. ${ }^{229}$

After a major hearing, the application was rejected. Possibly, the refusal would have come without the ecological importance of the area being considered - "the Board is not convinced Amoco has adequately demonstrated the need to locate the well at the

P. Rowbotham, "The Growth of Public Participation in Decisions of the Energy Resources Conservation Board" (1994) 32 Alta. L. Rev. 468 at 478. The Crown of the Continent, on the continental divide, is considered to include Waterton Park (whose Superintendent is on the Society's Board of Directors), Glacier Park in Montana, and adjacent mountains and foothill areas in Alberta, Montana and B.C. Waters from it flow to the Pacific Ocean, Hudson's Bay and the Gulf of Mexico (ibid. at 474).

Ibid. at 479.

ERCB, Application for an Exploratory Well Amoco Canada Petroleum Company Limited Whaleback Ridge Area Decision D 94-8 (1994).

ERCB, Oil and Gas Developments Eastern Slopes Southern Portion, Informational Letter 93-9 (13 December 1993).

ERCB, Applications for Well Licences Moose Mountain Area Husky Oil Operations Ltd. Decision D 94-2 (11 March 1994) at 13.

See S.A. Kennett, "The Whaleback Decision: All Clear on the Eastern Slopes?" (Fall 1994) 48

Resources 1. 
proposed location"230 - but biodiversity considerations certainly played a role in the decision. Intervenors suggested that the area involved, directly south of an ecological reserve, is "a unique assemblage of ... plants and animals" 231 and ripe for designation under the proposed "Special Places 2000," a program originally intended to ensure protection of adequate examples of all ecosystems in the province. Intervenors had claimed that the Whaleback represented the largest and least disturbed montane ecosystem in Canada. ${ }^{232}$ The ERCB agreed: "allowing oil and gas development in the Whaleback region prior to allowing the Special Places 2000 program to run its course would likely compromise its relative value to the program." ${ }^{233}$

A further reason for rejecting the application was that the Integrated Resource Plan (IRP) for the area, which had been approved as a non-binding policy guide by the Alberta cabinet,

appears to give priority to the protection of ecological and wildlife values.... The road extension in particular would appear, without ... additional mitigation, to be totally inconsistent with the intent of the IRP. ${ }^{234}$

The Whaleback decision, then, shows the commitment of a respected regulatory board to ecological values. The story, however, does not end there. The technical deficiencies in an application can be corrected and the Board specifically offered to reconsider the application after the province made a decision about the Whaleback's status as a "Special Place." If the Whaleback is not protected, (it was not on the government's first list of twenty-nine candidates, but even designation as a Special Place would not necessarily preclude developmen $t^{235}$ ), the Board, having found in the instant application that the need for the well and possibility of drilling it safely had been established by Amoco, might approve the application to drill. Although it could still refuse the well as not being in the public interest (it must not fetter its discretion by abdicating its judgement to Cabinet), de facto, the provincial decision concerning protection would have considerable effect in the Board's deliberations. If the applicant were able to prepare an access control plan consistent with the IRP, the likelihood of approval by the Board would be increased.

It could be argued, therefore, that the Whaleback decision is not as revolutionary as some have suggested. It did not state that the potential development of the area was unacceptable because of its ecological costs. That decision, paradoxically, may have to await the drilling of a well, contrary to the Board's stated desire to look at the overall development and not just a single well. "The Board believes that evaluation [of the

ERCB, supra note 226 at 14 . The Board also expressed some dissatisfaction with the public consultative process employed ("primarily reactive rather than proactive, and primarily advisory rather than consultative" (ibid. at 27)).

Ibid. at 33.

Ibid. at 31 .

Ibid. at 34.

Ibid. at 32-33.

The Calgary Herald (29 March 1995) A3. 
natural gas prospects in the Whaleback area] may eventually be in the long-term interest of Alberta." ${ }^{236}$

Important lessons from the Whaleback are that proactive land use analysis and designation should precede development applications and that a regulatory board hearing may not be the appropriate forum for such framework decisions. The Board is grappling with this difficulty, but a provincial perspective, preferably with binding criteria, is badly needed if non-development values like biodiversity are to be preserved.

The other board which must be considered is the NRCB, which, under the Natural Resources Conservation Board Act, ${ }^{237}$ complements the above-described EA regime under the EPEA. For our purposes, it is notable that flora and fauna are considered natural resources in the $N R C B A{ }^{238}$ The Board's mandate is to reach an impartial opinion as to whether or not reviewable projects are in the public interest, considering their social, economic and environmental effects. Written, significant objections to a project by a directly affected person normally trigger a public hearing. ${ }^{239}$

Reviewable projects include: lumber, veneer, panelboard or treated wood facilities; recreational; tourism; metallic or quarriable mineral projects, but only if an $E A$ has been ordered for the preceding list of projects under the EPEA process; ${ }^{240}$ all pulp, paper, newsprint or recycled fibre plants; sizeable ${ }^{241}$ water management projects; or any others prescribed by regulation. ${ }^{242}$ Regardless of other approvals, no one, including Crown agencies, may commence a reviewable project without the Board's approval. ${ }^{243}$ Board approvals, on any conditions considered appropriate by it, are subject to prior authorization by the Lieutenant-Governor-in-Council, who may add additional terms and conditions. ${ }^{244}$ Rejections by the Board cannot be reversed by Cabinet. Joint reviews with other boards or agencies are contemplated. ${ }^{245}$ Approval by the Board does not remove the need to obtain all other necessary licences or permits. ${ }^{246}$

No authority is given the Board to oversee the ongoing development or operation of a project, although the Board has implicitly circumvented this by imposing approval conditions requiring that work be satisfactory to another authority. ${ }^{247}$

\footnotetext{
236 Supra note 226 at 35.

237 R.S.A. 1980, c. N-5.5 [hereinafter NRCBA].

238 Ibid., s. $\mathbf{l}(\mathrm{g})$.

239 Ibid., s. 8(3) (unless the Board considers the objection "vexatious or of little merit").

240 This prerequisite EA order is part of the relevant definitions in s. (1) of the NRCBA.

241 Regulations specify the minimum height of barriers or volume of water affected.

242 Supra note 237, s. 4

243 lbid., s. $5(1)$.

244 Ibid., s. $9(1)$

$245 \quad$ Ibid., s. 20.

246 Ibid., s. 9(3).

247 E.g., that the Town of Canmore be satisfied with a safety assessment ordered to be done and that the developer undertake any remedial action required by the Town. See M. Chamberlain \& D. Perret, "The Three Sisters Decision: the NRCB Flexes Its Muscle" (1993) 4 J.E.L.P. 207 at 210.
} 
Thus, the enhancement of biodiversity depends on the Board's own balancing, without guidance from the Legislative Assembly, of social, economic and environmental effects and on consequent approval conditions for any project it deemed to be in the public interest. The Three Sisters decision ${ }^{248}$ shows the Board's present willingness, in some situations, to give preeminence to species and habitat values. There, the applicant envisaged more than 6,000 housing units, 2,425 hotel rooms and four golf courses, on over 1000 hectares in Canmore, in the Bow River corridor, just east of Banff National Park. ${ }^{249}$ Lands in Wind Valley, which is of unusual biological richness, were owned by the applicant: in fact, they constituted about one quarter of the subject property. The Board, while conditionally approving the overall application, excluded the Wind Valley lands from the approval, which stimulated a land trade with the Province.

Golf course and/or residential proposals in the area (six courses have been approved, plus one more in Kananaskis ${ }^{250}$ ), have been subject to more basic criticism by environmentalists. Many believe that the sizeable developments contemplated in the Kananaskis and Bow River Valleys will inevitably displace wildlife in spite of the preservation of some habitat like Wind Valley and ameliorative requirements such as wildlife corridors ${ }^{251}$ in development approval decisions. The Board is conscious of this danger of habitat fragmentation and alienation, ${ }^{252}$ but the basic development ethos can be dealt with only at the political level and the present government clearly supports it.

What follows from this lengthy discussion is that preserving biological diversity under the EPEA, the ERCB and the NRCB depends largely on the personal commitment of the Minister of Environmental Protection and the particular board members who happen to hear an application. Although often commentators call for independent boards to be created to make these kinds of decisions, ${ }^{253}$ there is great danger in allowing democratically unaccountable persons to do so without clear legislated criteria to guide them. Indeed, decisions of this sort are so value-dependent that, arguably, elected representatives should make the final ruling.

\section{WILDLIFE LEGISLATION}

The Wildlife $A c t^{254}$ is clearly oriented to sustainable management of the game resource to optimize hunting, but aspects of it do relate to conservation of endangered,

Alberta Natural Resources Conservation Board, Decision Report Application \#9103 - Three Sisters Golf Resorts Inc. Application to Construct a Recreational and Tourism Project in the Town of Canmore, Alberta (November 1992).

Ibid. at 2-2, 2-3. One of the golf courses, on other Three Sisters land, had already been approved before the $N R C B A$ was proclaimed (ibid. at 1-1 \& 11-3).

lbid. at $11-5$.

The Board recommended to Alberta Forestry, Lands and Wildlife that primary corridors be required to have, except in unusual circumstances, a minimum width of $350 \mathrm{~m}$ (ibid. at 10-38).

See ibid. at 10-22.

See infra, text accompanying note 424 .

S.A. 1984 , c. W-9.1. 
as well as game, species. For example, it establishes the Fish and Wildlife Trust Fund for funding, inter alia, "prescribed programs for the protection and enhancement of fish and wildlife and their habitats." ${ }^{255}$ As well, compensation is to be provided, inter alia, for damage caused by wildlife and the costs to prevent same. This provision should reduce the political pressure from livestock interests to control predators. Finally, humane trapping programs are to be promoted. ${ }^{256}$

Money for the Fund comes largely from hunting and fishing licences or permits, donations, bequests and fur royalties. ${ }^{257}$

The property in all live wildlife ${ }^{258}$ is vested in the Crown. ${ }^{259}$ No one may possess a wild or exotic animal unless permitted by the Minister, or unless possession is incidental to the operation of a fur or game animal production farm. ${ }^{260}$ Trafficking in wildlife is forbidden unless specifically authorized by a permit. ${ }^{261}$

Genetic integrity of wildlife is enhanced by the power of the Minister to order quarantine, seizure or killing of any wildlife, exotic or excluded animal if he believes it "poses an ecological threat or genetic danger to wildlife and that it is in the public interest to do so." 262

Finally, considerable enhancement of wildlife habitat could be achieved under regulatory powers in the Wildlife Act. The Lieutenant-Governor-in-Council may establish wildlife sanctuaries and habitat development areas. ${ }^{263}$ The Minister may by regulation establish these and other areas (migratory bird lure sites and wildlife control areas) for a part of the year. ${ }^{264} \mathrm{He}$ or she may also regulate the protection and restoration of habitat, requiring persons to restore habitat altered by them. ${ }^{265}$

The Livestock Industry Diversification Act ${ }^{266}$ legalizes game farming in Alberta, a practice which could significantly harm biological diversity. Persons require a non-

Ibid., s. 6(a). See the Fish and Wildlife Trust Fund Regulation, Alta. Reg. 277/85 as am. Expenditures from this fund averaged $\$ 8.3$ million dollars per year from 1991-92 to 1993-94 (Hon. Ty Lund, Minister of Environmental Protection, pers. comm., Mar. 2, 1995). Wildlife Act, ibid., ss. 6(b), 6(c).

257 Ibid., s. 7(1).

238 Species which have been prescribed (by the General Wildlife Regulation Alta. Reg. 50/82 as am.) as big game, birds of prey, endangered animals, fur-bearing animals, migratory game birds, non-game animals, non-licence animals and upland game birds (supra note 254, s. $1(1)(x)$ ). An animal is defined as all vertebrates but fish and humans (ibid., s. 1(1)(a)). Unless the Minister has transferred an interest in captive wildlife to someone else, in which case neither it nor its progeny belongs to the Crown (ibid., s. 10).

Ibid., s. 54.

Ibid., s. 61.

Ibid., s. 79.

Ibid., s. 96(d). Twenty-eight sanctuaries of various sorts have been established, as have three habitat development areas (the latter totalling 2423 hectares - Hon. Ty Lund, Minister of Environmental Protection, pers. comm., Mar. 2, 1995).

lbid., s. 97(f).

Ibid., s. 97(j).

S.A. 1990, c. L-22.7. 
transferable, ${ }^{267}$ annual ${ }^{268}$ licence to operate a game animal production farm. ${ }^{269}$ They must also have an estate in the land where the farm will be operated. ${ }^{270}$ All game production animals must be registered and in captivity ${ }^{271}$ and the licence specifies what species may be farmed. ${ }^{272}$ Reasonable efforts are to be made to prevent wild animals of the farmed species from coming on the property. ${ }^{273}$ The sale and slaughter of game production animals are controlled by the $A c t^{274}$ and provision is made for quarantine and destruction of animals if infectious diseases or other dangerous conditions are suspected. ${ }^{275}$ Regulations may be promulgated concerning the "genetic composition" of game production animals allowed or prohibited on farms. ${ }^{276}$ Four species have been approved for game ranching: mule deer, white-tailed deer, moose and elk. ${ }^{277}$

The creation of commercial markets for wild animal meat or body parts is very controversial in Alberta. Valerius Geist, an eminent wildlife biologist and ecologist, has eloquently described the many shortcomings of game ranching. ${ }^{278}$ Major disadvantages, which have already eventuated, include the escape of game production animals and the creation of hybrid animals or feral herds competing for an ecological niche.

As well, disease is a major problem, particularly bovine tuberculosis. Deer and elk are susceptible to it and it can spread to wild herds, as well as back to uninfected cattle. Control, including testing, is very expensive. In Alberta, at least 2,400 elk have been destroyed for this reason since the legislation was proclaimed in $1991 .{ }^{279}$ In New Zealand, 410,000 deer were tested in 1992. It may be technically impossible to eradicate bovine TB in wild-living wildlife in five large areas of New Zealand where the disease is now endemic. As well, the export of beef, dairy and wildlife products from New Zealand has been jeopardized because of bovine TB. ${ }^{280}$

Alberta's wildlife legislation offers only rudimentary protection to endangered species, although habitat preservation programs are being implemented with the cooperation of such organizations as the World Wildlife Federation, the Nature

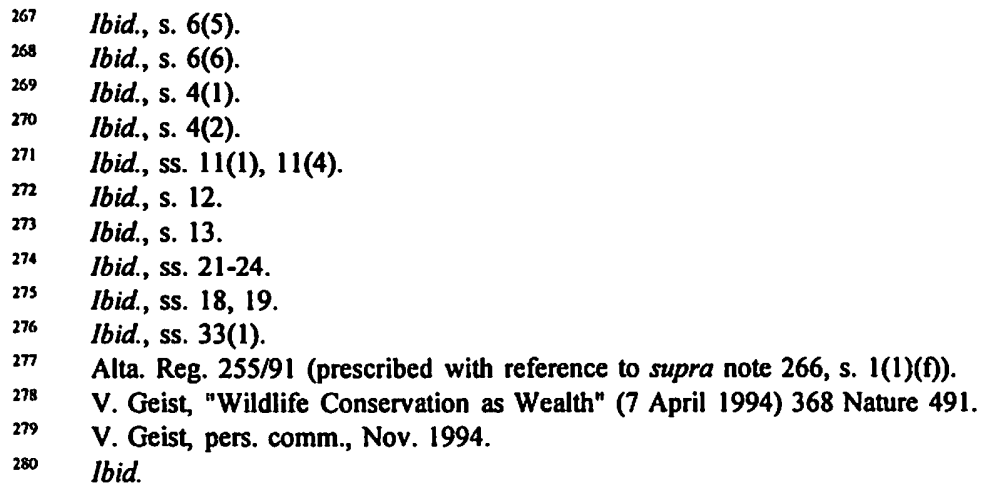


Conservancy and Ducks Unlimited. ${ }^{281}$ Specific suggestions for changes will be made later, but reconsideration of game farming is recommended.

\section{E. PUBLIC LANDS LEGISLATION}

Although the Public Lands $\mathrm{Act}^{282}$ can have significant impact on biodiversity through the disposition of estates or interests in public land for homesteads, grazing, commercial or various other purposes, not many provisions in it specifically address this issue. The Lieutenant-Governor-in-Council is given perhaps redundant power, given other statutes we are examining, to set aside public land for use, inter alia, as provincial park, natural area, ecological reserve, wilderness area, forest reserve, wildlife sanctuary or habitat development area. ${ }^{283}$ Authority also exists to permit the Minister responsible for Forestry, Lands and Wildlife to transfer land to Canada for a national park. ${ }^{284}$

The Farm Development and Homestead Regulation ${ }^{285}$ allows public land to be conveyed for farm and homestead purposes only if in the opinion of the Minister, it is not required for various other purposes, including "watershed protection or other conservation purposes."1286 Agencies like Fish and Wildlife register their habitat concerns on an automated system and these are considered when applications are made. $^{287}$

The Forest Management Area Grazing Licence Regulations ${ }^{288}$ and the Public Lands Grazing Lease Regulations ${ }^{289}$ both require lessees to employ proper range management and conservation principles. The Minister's discretion to lease land, however, is not constrained by any criteria.

Under the North American Waterfowl Management Program, almost 245,000 acres of uplands and wetlands "are now being managed by Albertans for wildlife habitat and environmentally sustainable agriculture benefits" (Alberta Environmental Protection (Fish and Wildlife Services) et al., Partnerships: Caring for the Land (Edmonton: North American Waterfowl Management Plan, 1994) at 2). Other enhancement programs involve Trout Unlimited, the Cattle Commission, Canadian Cattle Association and Alberta Fish and Wildlife (Heather Gerling, Public Land Management Branch, Department of Agriculture Food and Rural Development, pers. comm., Dec. 20, 1994). R.S.A. 1980 , c. P-30.

Ibid., s. 7(c). Tax recovery lands are sometimes exchanged for more sensitive areas. About ten years ago, three and one half townships of tax recovery land near Medicine Hat were so exchanged (Gerling, supra note 281).

Public Lands Act, ibid., s. 7(g).

Alta. Reg. $234 / 85$ as am. by 296/87, 138/88. As of Feb. 24, 1993, the Departments of Environmental Protection and of Agriculture, Food and Rural Development shared the management of public lands under agricultural disposition (A. J. Kwasniak, Alberta Public Rangeland Law and Policy (Edmonton: Environmental Law Centre, 1993) at 16).

Ibid., s. 2(b).

Gerling, supra note 281.

Alta. Reg. 309/71, s. 17.

Alta. Reg. 432/66, s. 8. 
The Public Grazing Lands Range Improvement Regulation ${ }^{290}$ could have significant adverse effects on biological diversity. The Minister may totally finance "improvements" to a grazing disposition, for the "clearing, breaking ... and seeding of brush covered .... and other low productivity lands to tame forage species...." 291 Other eligible activities are the "spraying, burning, mowing, fertilizing or other measures to maintain the range and to control brush encroachment." 292

These provisions are an invitation for publicly funded reduction of biodiversity and could well be repealed.

The Public Lands Act has been called detrimental to wetlands because s. 3 limits Crown ownership of beds and shores to permanent bodies of water. This implies, it is felt, that "the beds and shores of all non-permanent wetlands ... are privately owned and, therefore, may be managed so as to benefit individual landowners at the expense of societal interests. ${ }^{1293}$ If a correct interpretation of the Act, this is regrettable. In my opinion, drainage of these areas is illegal without a permit under s. 5 of the Water Resources Act, about to be discussed, although few persons, at least in the past, bothered to apply for permission. A combination of public education and enforcement of the permit requirement would improve this situation.

Other powers which could be exercised to maintain biodiversity include the Lieutenant-Governor-in-Council's power to make regulations restricting the uses to be made of land disposed of under the Public Lands Act. ${ }^{294}$ Furthermore, the Minister may classify public land and declare for what uses the classes are considered to be adaptable. ${ }^{295}$ She or he may also restrict, or withdraw from, disposition of any public land ${ }^{296}$ or prescribe terms and conditions for any disposition. ${ }^{297}$

No criteria, however, are provided in the Act to guide the Minister in deciding on homesteading, cultivation, grazing ${ }^{298}$ or other applications for dispositions, ${ }^{299}$ although the promotion of practices to prevent soil drifting or overgrazing may be undertaken by her. ${ }^{300}$ Any activity likely to injure the surface of the public land needs authorization. ${ }^{301}$

Alta. Reg. 221/80, as am.

Ibid., s. 9(a).

Ibid., s. 9(c).

Tkachuk, supra note 186 at 15.

Supra note 282, s. 8(1).

Ibid., s. 10.

Ibid., s. 13.

Ibid., s. 14.

Grazing leases of up to twenty years may be issued if the minister is of the opinion that the best use of the land would be the grazing of livestock (ibid., s. 106(1)).

Dispositions do not include mines or minerals or the right to work them (ibid., s. 34(1)).

lbid., s. 17(a).

Ibid., s. 50. 
Again, the lack of any obligation to consider biological diversity when exercising powers under this legislation is noteworthy. Also, it is suggested, certain outdated provisions should be repealed.

\section{F. PRESENT AND PROPOSED WATER LEGISLATION}

The Water Resources $\mathrm{Act}^{302}$ is meant to achieve socially optimal distribution of a precious resource in our semi-arid climate. The property of all water in Alberta, on or under the surface of the ground, is vested in Her Majesty. ${ }^{303}$ This, in principle, means that water in sloughs cannot be used or diverted, except for domestic use, even by the person who owns the underlying land.

At least as to water quantity, no riparian rights to the continued natural flow of watercourses survived the passage of the Act (although no permit is needed for landowners to use water for domestic purposes). ${ }^{304} \mathrm{~A}$ mixed, hierarchical licence system is established for the use and diversion of water, with the first cut by the timing of the application or of the licence (the standard prior appropriation approach). However, the Act lists uses in order of priority (e.g. in descending order: domestic; municipal; agricultural (including irrigation); industrial; and water power and other like purposes) and allows persons wishing to use water for higher priority uses to apply to the Minister to have licences for lower priority uses to be cancelled (with compensation). Otherwise, earlier licences (which appear to last indefinitely) obtain all their entitlement before later ones get anything. ${ }^{305}$ This is important for our topic, as conservation and natural state licences, mentioned four paragraphs below, were not authorized until 1971. Thus, all earlier licences will get their full allocation even if insufficient water remains for the conservation licensee.

Many licences issued under this Act have resulted in degraded or destroyed wetlands, ${ }^{306}$ although, as a matter of policy, wetland drainage applications are circulated to the Fish and Wildife Division of Alberta Forestry, Lands and Wildlife. ${ }^{307}$ It will be recalled, however, that water management projects are subject to the EA process under the $E P E A$, described earlier. Most will be in the non-mandatory category, requiring a Director's decision.

R.S.A. 1980, c. W-5.

Ibid., s. 2(1).

Ibid., s. 2(2).

Ibid., s. 35(1).

Tkachuk, supra note 186 at 17. The Drainage Districts Act, R.S.A. 1980, c. P-9 and the Irrigation Act, R.S.A. 1980, c. I-11 are also noted by Tkachuk as largely militating against wetlands through their focus on improving agricultural production with single-use, drainage or irrigation projects (Tkachuk, ibid. at 19).

R. Usher \& J. Scarth, Alberta's Wetlands: Water in the Bank (Edmonton: Environment Council of Alberta, 1990) at 28. Percy, however, has not "discovered any instance in which an application for a drainage licence ... has been denied because of its effect on wetlands" (Percy, supra note 107 at 98 ). Allocation limits are, however, designed to protect fish habitat (Hon. Ty Lund, Minister of Environmental Protection, pers. comm., Mar. 2, 1995). 
Livestock watering practices can result in serious destruction to shorelines or wetland margins and hence to nesting or breeding areas. ${ }^{308}$ The $A c t$ 's failure to regulate this activity is unfortunate. ${ }^{309}$

It should also be noted that the Minister may use public funds to implement water projects for various listed purposes such as drainage, which would tend to detract from habitat conservation. ${ }^{310}$ The general power in s. 83(1), however, leaves the range of purposes to the Minister's absolute discretion "in the best interests of Alberta." Conceivably, habitat preservation, although not listed as a specific objective, could motivate the Minister.

Other provisions in the Act could also help maintain biodiversity. Sections 11(1)(b) and (c), the next priorities below in the hierarchy listed above, contemplate licences to impound water, or to use it in its natural state, for "conservation, recreation or the propagation of fish and wildlife." 311 Further, the Lieutenant-Governor-in-Council may authorize the granting of non-cancellable licences for any use listed in s. $11 .{ }^{312} \mathrm{He}$ may also intervene in an emergency to direct how water is to be used. ${ }^{313}$ This power, of course, could be exercised either for or against biodiversity interests. As well, the Lieutenant-Governor-in-Council may require fishways to be built in any dams or other works and operated appropriately. ${ }^{314}$ The Minister can have surveys made of streams or sources of water supply for any purpose, so that again, habitat preservation could be considered. $^{315}$ The Water Power Regulation ${ }^{316}$ contains some provisions which could be relevant to our subject. An applicant for a licence to use water for power purposes must show "what provisions are being made for navigation, logging or other interests. ${ }^{" 17}$ It will be no surprise that licensees must

comply with the provisions of any provincial or federal statute or regulation goveming the preservation of the purity of waters or governing logging, forestry, fishing, or other present or future interests which may be affected.... ${ }^{318}$

In addition, however, any instructions given by the Minister regarding these matters must be carried out, so long as they are not inconsistent with the laws mentioned. Thus,

Tkachuk, supra note 186 at 17.

Kwasniak argues that s. 51(d) of the Public Lands Act and possibly the EPEA could be used to regulate livestock operations (supra note 285 at 115-26).

Supra note 302, ss. 83-91.

Although, to 1993, only one natural state licence had ever been issued, others for impoundments for conservation or the propagation of fish and wildlife have been obtained (Percy, supra note 107 at 85, 86). Percy's discussion is invaluable for those interested in wetlands preservation.

Supra note 302, s. 12(3).

Ibid., s. 13(1).

Ibid., s. 72(d.1).

Ibid., s. 73(2)(a).

Alta. Reg. 72/91.

Ibid., s. 5(3)(d).

Ibid., s. 66(b). 
biological diversity could be relevant, although it certainly does not take a front row seat.

As this article went to press, the Minister of Environmental Protection introduced a new Water Act into the Legislative Assembly. ${ }^{319}$ This bill would make several changes to the water management and conservation legislation just described. Among them is the apparent disappearance of the hierarchy of water uses and of the right for senior users to apply for prior but junior licences to be cancelled. ${ }^{320}$ There is, however, a very limited hierarchy. Riparians rank first for household purposes. ${ }^{321}$ Traditional agricultural users seem to rank next, because they get their date/time priority based on their first use of the water, not the date of the registration of their use. . $^{322}$ Otherwise, priorities are determined solely by the seniority of the licence. ${ }^{323}$ This means that new licences awarded for biodiversity purposes will still start off at the bottom.

Under the new bill, water management plans would be prepared within a framework and strategy prepared by the Minister. ${ }^{324}$ The strategy may include "matters relating to the protection of biological diversity. ${ }^{1325}$ The plans' contents would have to be considered in approval decisions and potential or cumulative effects on the aquatic environment could also be taken into account. ${ }^{326}$ The plans could adopt an integrated approach concerning land, water and other resources. ${ }^{327}$ The Minister will be able to veto the granting of any approval or licence under the $A c t .{ }^{328}$ Permits and licences, including existing ones, would now have an expiry date. ${ }^{329}$

A licence could be issued to the government for meeting instream needs for a water conservation objective so long as private users are not adversely affected. ${ }^{330}$ Two points should be noted here. First, the earlier Discussion Draft on the intended legislation stated that the government licence would take priority over licences issued

Bill 51, 1995.

See text accompanying supra notes $305,306$.

Supra note 319 , s. 27 . Section 22 also clarifies the common law position of riparians: they cannot sue licenced diverters for reductions in the natural flow, but their rights to water quality are unaffected by the $A c t$.

lbid., s. 25. Traditional users may obtain water for animals and applying pesticides up to the limited amount of 6,250 cubic meters per year (s. 78(1), plus the riparian entitlement, if applicable, for household purposes (s. 25(1))).

Ibid., s. 30.

Ibid. ss. 8-12.

Ibid., s. 9(2)(c).

Ibid., ss. 13, 38(5).

Ibid., s. 10(2).

lbid., ss. 39(1), 56(1).

Ibid., s. 24(4)(b) (previously granted permits without an expiry date expire ten years after the new Act comes into force); s. 53(6) (licences must now be for a time specified under the regulations).

Ibid., s. 53(2) (No provision is made for private individuals to initiate an application for such an instream or conservation licence). 
under the proposed legislation to private parties, not vice versa. ${ }^{331}$ Second, water conservation objectives include "protection of tourism ... and waste assimilation uses" as well as "protection of ... aquatic environment" and "management of fish and wildlife. ${ }^{1332}$

Temporary assignments of water by traditional agricultural users or licencees would be permitted under certain circumstances, including the necessity that there be "no adverse effects on the ... aquatic environment." ${ }^{333}$ If a transfer of a licence (presumably through the sale of the water rights) were to be approved, a 10 percent water conservation holdback might be imposed. ${ }^{334}$ Finally, registrable conservation easement agreements could be entered into by the Minister. ${ }^{335}$

The new bill would empower the Director to suspend or cancel a licence where, inter alia, she is of the opinion that "there is a significant adverse effect on the aquatic or riparian environment that was not reasonably foreseeable at the time the licence was issued. ${ }^{1336}$ Furthermore, the Director could establish water management areas for various purposes, including "that applications for licences cease to be accepted," or even "directing that the diversion of water for household purpose cease." ${ }^{337}$ Also, a licence renewal must be refused if the Director, after a public review, believes it would cause damage to the aquatic environment. ${ }^{338}$ These provisions could make a significant contribution to biological diversity, although the Director could decide that since an expiring licence had already caused the harm, a renewal would merely maintain that impaired status quo and not cause new damage.

As just indicated, the proposed legislation could enhance biological diversity, although it missed several opportunities to stress conservation objectives. Conservationoriented water legislation might have been expected to ensure the priority of instream flows, instead of treating them as one of a number of competing objectives. As well, the former possibility for private citizens to apply for conservation licences has disappeared. ${ }^{339}$ Further, no hint of charging for the quantity of water diverted appears in the bill, although this would provide the necessary incentive for efficient use and help to enhance instream flows. It is to be hoped that vigorous planning and administration will incorporate biodiversity considerations, even though the bill could have been more directive in this regard.

Alberta Environmental Protection, Discussion Draft of Legislation (Edmonton: Alberta Environmental Protection, 1994), with public meetings in October \& November, 1994, s. 28(5). Supra note 319, s. 1(1)(aaa).

lbid., s. 34(1).

Ibid., S. 89. Bankes suggests that the Director's power to issue an instream flow licence for the amount of the conservation holdback should be made obligatory, since the exercise of the holdback is on the finding of need for the continuance of the flow. See N. Bankes, "Water Law Reform in Alberta: Paying Obeisance to the 'Lords of Yesterday,' or Creating a Water Charter for the Future?" (Winter, 1995) 49 Resources 1.

Ibid., s. 7.

Ibid., ss. 43(1)(vi), 44 (1)(viii).

Ibid., s. 17(e), (d).

lbid., s. 87(2).

See text accompanying supra note 311 . 


\section{G. AGRICULTURAL LEGISLATION}

The Agricultural Pests Act gives broad powers to the Minister of Agriculture to declare animals, birds, insects, plants or diseases to be agricultural pests. ${ }^{340} \mathrm{Big}$ game, birds of prey, game birds or endangered animals, however, cannot be so designated. ${ }^{341}$ The Minister may establish programs to control or destroy these pests and landowners are obliged to take active measures to control or destroy them, including the destruction of any crop or vegetation which contributes to their maintenance or spread. ${ }^{342}$ An inspectorate is established to implement the $A c t$ and the use (and regulation) of poisons or insecticides is envisaged. ${ }^{343}$

An aggressive, single-minded Minister could exercise the powers under the Act in a manner quite detrimental to biological diversity. Perhaps understandably, agricultural production is the preeminent value under this legislation.

Section 7(1) of Alberta's former Department of Agriculture Act ${ }^{344}$ provided for loan guarantees for clearing and breaking land for agricultural purposes. Although this was no doubt appropriate in the past, the conversion of new areas to agriculture might usefully be re-examined in the present context. To be sure, the provision of loan guarantees for clearing and breaking land is less significant than the overall homesteading program under the Public Lands Act, discussed above. ${ }^{345}$

Other agriculturally-oriented legislation with implications for biodiversity include the Drainage Districts Act $^{346}$ and the Irrigation Act. ${ }^{347}$ These statutes provide means for altering wetlands or other aquatic environments for agricultural purposes through draining them or altering them to enhance water storage or flow. The $D D A$ allows local drainage districts to be formed by petitioning the Minister administering the $D D A$. The board administering the district must obtain approval under the Water Resources Act for the proposed works. ${ }^{348}$

S.A. 1984 , c. A-8.1, s. 2.

Ibid., s. 2(2).

lbid., s. 5(2).

lbid., s. 2 l(n)-(q).

Repealed by Government Organization Act, S.A. 1994, c. G-8.5. Under the Range and Soil Improvement Program, about $\$ 21.5$ million was lent and $\$ 4.465$ million paid in incentives from April 1, 1980 to March 31, 1994 (Len Fullen, Resource Planning Branch, Alberta Agriculture Food and Rural Development, pers. comm., Feb., 1995).

From 1986-1990, some 90,500 acres, two-thirds of which were classified as marginal farmland (Canada Land Inventory $4 \& 5$ ), were added to Alberta's farm land, mostly by the sale of public lands. A net loss over this period was about 100,000 acres, 70 percent of which were better agricultural land (Canada Land Inventory 1-3) (Resource Planning Branch, Alberta Agriculture Food and Rural Development, Agricultural Land Base Monitoring Study (1986-1990) (Edmonton: Alberta Agriculture, 1993)).

R.S.A. 1980 , c. D-39 [hereinafter $D D A]$.

R.S.A. 1980 , c. I-11.

Supra note 346, s. 38 . 
No new districts have been formed since the 1950 s and some 77,000 hectares are included in the nine existing districts. ${ }^{349}$

The Irrigation Act operates on a much larger scale. Thirteen districts (created by petition to the Irrigation Council by most of the owners in the area) cover over 600,000 hectares of land. ${ }^{350}$ Bringing arid land into agriculture has adversely affected natural habitat, including nearby wetland or waters which provide the necessary water ("irrigation works" include drainage works ${ }^{351}$ ). On the other hand, some wetlands have benefited from water provided through irrigation projects. ${ }^{352}$

Provision is made in the Irrigation District Rehabilitation Endowment Fund $\mathrm{Act}^{353}$ for rehabilitating irrigation works.

The Soil Conservation $\mathrm{Act}^{354}$ could be relevant to our topic. Landholders must, and may be ordered to, take appropriate measures to stop or prevent soil loss or deterioration from taking place. ${ }^{35 s}$ While in principle the conservation of soil is desirable for biodiversity, modern agricultural practices, policies and legislation have affected it adversely. ${ }^{356}$ In contrast, it has been claimed that European "traditional agriculture generally encouraged a greater diversity of species." 357

Agricultural legislation needs an overhaul with biological diversity in mind. For example, the Drainage Districts Act could well be repealed. ${ }^{358}$

\section{H. FORESTRY LEGISLATION}

Forestry practices in Alberta, as in many other jurisdictions, are controversial. Under the Forests Act, ${ }^{359}$ huge areas of the province have been designated as forest management units or leases. ${ }^{360}$ Although the statute refers to the "establishing, growing and harvesting timber ... to provide a perpetual sustained yield," many doubt that present management, timber harvesting and reforestation practices will achieve this goal. From the biodiversity standpoint, however, even this is not the fundamental

\footnotetext{
$349 \quad$ Usher \& Scarth, supra note 307 at 29.

350 Ibid.

351 Supra note 347, s. 1(m).

352 Usher \& Scarth, supra note 307.

353 S.A. 1992, c. I-11.5.

354 S.A. 1988, c. S-19.1.

$35 s \quad$ lbid. ss. 3, 4.

See text accompanying infra notes 409-410. See also R.D. Sopuck, Canada's Agricultural and Trade Policies: Implications for Rural Renewal and Biodiversity (Ottawa: National Round Table on the Environment and the Economy, 1993) at 14, 31-36.

I. Voluscuk, "EECONET (European Ecological Network) and Forests" in G. Bennett, ed., supra note 2 at 104.

Percy, supra note 107 at 102.

R.S.A. 1980 , c. F-16.

A single agreement dedicated about 61,000 square kilometres of Crown land, an area larger than New Brunswick, to one company's (Alberta Pacific's) operations (L. Pratt \& I. Urquhart, The Last Great Forest (Edmonton: NeWest, 1994) at 141).
} 
question. Rather, what bothers conservationists is the assumption that old-growth forests should be clearcut and that replanted areas should be managed as a single crop, single age-class plantation. ${ }^{361}$ Many species depend on old-growth forests for survival.

The Minister of Environmental Protection, who is now responsible for Forestry, Lands and Wildlife, and who might be expected to support wildlife as well as timber values, is empowered to regulate logging methods. ${ }^{362}$ Reforestation regulations, inter alia, are a matter for the Lieutenant-Governor-in-Council. ${ }^{363}$ Clearcutting is one of the most controversial issues and many companies are adjusting the size of their clearcuts. $^{364}$ In Alberta, agricultural, energy and forestry activities are probably the three most significant variables in the biodiversity equation.

The Timber Management Regulation ${ }^{365}$ orders the Minister to "manage the forest resources in accordance with established forestry practices and in the economic interest of the public." ${ }^{366}$ This duty would enable the incorporation of progressively more stringent conservation and biological diversity principles, contingent on the evolution of the forestry profession. Otherwise, not much is said in the regulations about items relevant to our subject. They require quota holders to pay a penalty for cutting less than 90 percent of the quota volume. ${ }^{367}$ Overcutting is also penalized. ${ }^{368}$ Operators on public land must dispose of any debris or locate any structure or excavation without impeding the natural flow of or polluting any body of water. ${ }^{369}$

Provisions are made for the progressive reforestation of harvested areas, in accordance with a plan approved by the Minister. ${ }^{370}$ Selective cutting "to improve a timber stand" may result in relief from these obligations. ${ }^{371}$ The Minister may construct and maintain forest recreation areas and trails, ${ }^{372}$ although the characteristics

It should, however, be noted that many forests originated as even age stands after fires. Early succession species, such as lodgepole pine or aspen, may be suitable for clearcuts when timber production is the over-riding goal. In later stages of succession, mixed wood areas or where habitat protection is a major objective, selective cutting or small clearcuts with irregular boundaries may be the preferable harvesting technique (Expert Panel, supra note 128 at 37-40). Supra note 359, s. 5(a).

Ibid., s. 4(f).

E.g., Alberta-Pacific planned to limit their clearcut areas to twenty-five to sixty hectares, in order to protect critical habitat and plant diversity (The Alberta-Pacific Environmental Impact Assessment Review Board, The Proposed Alberla-Pacific Pulp Mill: Report of the EIA Review Board (March, 1990) at 9).

Alta. Reg. $60 / 73$ as am. The title change from plural to singular occurred through Alta. Reg. $163 / 85$.

Ibid., s. 164.

Timber Management Amendment Regulation, Alta. Reg. 338/79, s. 5.

Supra note 365, ss. 21, 22 (as replaced by Alta. Reg. 18/94, ss. 4, 5).

lbid., s. 100(i). Persons clearing land for an industrial use have a similar obligation (s. 146).

Ibid., s. 123 (unless the Minister provides otherwise). See also Alta. Reg. 60/91, ss. 19-26 which establish a new regime for reforestation.

"Alberta's success in reforestation is generally satisfactory," although subsequent maintenance of replanted areas has not been as successful (Expert Panel, supra note 128 at 70).

Ibid., s. 129.

Supra note 359, s. 11. 
of these areas are not defined. Some 224 exist, containing various facilities for activities like picnicking and camping. ${ }^{373}$ Biological diversity does not appear to be a goal here.

If the Minister forms the opinion that it is in the public interest that any provision in a timber permit, licence or quota should be changed, it may be varied accordingly. ${ }^{374}$

Forest reserves set apart under the Forest Reserves Act are "established for the conservation of the forests and other vegetation in the forests," as well to support an optimum water supply ${ }^{375}$ (which in itself, of course, should enhance aquatic biodiversity). A considerable area, about 2.32 million hectares in the Eastern Slopes, is so reserved. ${ }^{376}$ Nevertheless, forest harvesting in the Reserves is treated the same as in other Crown forest areas. Grazing, guiding and outfitting activities are regulated under this Act. As well, most other resource exploitation activities are permitted in these areas by the Minister or by regulations authorized under the Act. Thus, this Act, notwithstanding its title, offers little, if anything, for biological diversity.

The Forest and Prairie Protection $\mathrm{Act}^{377}$ creates a regime for the prevention and control of fires in the rural areas of Alberta. Controversy exists about the appropriate role of fires in land management and the Act recently was amended to permit forest officers to start fires for the purpose of, inter alia, "managing wildlife habitat." ${ }^{378}$ No other protection for biodiversity is offered by this legislation.

More explicit duties to integrate biodiversity objectives into forestry management are required in Alberta's forestry legislation.

\section{LEGISLATION ON MINERALS}

The Mines and Minerals $\mathrm{Act}^{379}$ applies to all Crown mines and minerals, including oil, natural gas and oil sands. Under the Act and regulations, persons must apply for and obtain an agreement or lease which grants rights over a mineral owned by the Crown before undertaking exploration or development. The issuance of agreements granting rights to minerals in any area may be refused ${ }^{380}$ or restricted. Minerals in specified locations, such as those listed in Category I under the Coal Development Policy, or zoned as Prime Protection in the Eastern Slopes may be, and are, withdrawn from disposition by the Minister. ${ }^{381}$ Furthermore, the Minister, if of the opinion that

Hon. Ty Lund, Minister of Environmental Protection, pers. comm., Mar. 2, 1995.

Supra note 359, s. 26.

R.S.A. 1980 , c. F-15, s. 4.

Ann Mcinemey, Executive Coordinator to the Assistant Deputy Minister, Lands and Forests, pers. comm., Jan. 24, 1995.

R.S.A. 1980 , c. F-14.

Ibid., s. 28.1 (enacted in S.A. 1991, c. 14, s. 6.).

R.S.A. 1980, c. M-15.

Ibid., s. 18(a).

Ibid., s. 17; Hon. Patricia Black, Minister of Energy, pers. comm., Feb. 1, 1995. The withdrawal under the Coal Development Policy is of coal only. 
exploration or development of any minerals is not in the public interest, may expropriate any interest in them, or cancel or refuse to renew an agreement concerning them, subject to the provision of compensation. ${ }^{382}$ Applications for mineral rights may be refused. Thus, should an area be identified as important for biological preservation, mineral exploration or development could be excluded. As well, the LieutenantGovernor-in-Council may make regulations concerning the areas, conditions and the manner in which, exploration and development are to be permitted. ${ }^{383}$

Obviously, the approval of exploration and development activities, with their attendant roads and infrastructure, can have significant adverse impacts on biological diversity. It is hard to see much protection of biodiversity in the regime provided for mineral exploration and development. In 1993, the Exploration Regulation, also promulgated under the authority of three other Acts, ${ }^{384}$ was amended to remove the requirement that applications for exploration approvals be referred for review by the Department of the Environment if the bed or shore of a permanent watercourse or body was to be used ${ }^{385}$ Review by local forestry (Green Area) or the Rural Development Division of Agriculture, Food and Rural Development (White Area) officials is still provided for. ${ }^{386}$

The Pipeline Act authorizes the ERCB, which approves and regulates pipeline activities, to make regulations as to the measures in construction, all operations and the abandonment of pipelines for the protection, inter alia, of wildlife. ${ }^{387}$ Apart from the contemplation in the Pipeline Regulation that an application for surface use will be made to Forests, Lands and Wildlife for pipeline routes over vacant Crown land, ${ }^{388}$ no other relevant provision appears to have been made.

The ERCB may, however, on its own motion (or when required by the LieutenantGovernor-in-Council) shall "investigate any matter relating to ... conservation of the environment in the development and operation of pipeline facilities." ${ }^{389}$

In this sector as well, the ecosystem approach to land management would be enhanced by legislative amendments.

Ibid., s. 8(1).

Ibid., s. 152(a), (b). See the Exploration Regulation, Alta. Reg. $32 / 90$ as am. \& the Metallic and Industrial Metals Exploration Regulation, Alta. Reg. 95/91 as am.

Alta. Reg. 32/90. (The other Acts are the Forests Act, Public Highways Development Act, R.S.A. 1980, c. P-28 and Public Lands Act).

Exploration Regulation, ibid., s. 12 (repealed by Alta. Reg. 300/93, s. 6).

Ibid., s. 14; Alta. Reg. 300/93, s. 7. The Green (undeveloped, forested) and White (arable, developed) Areas of Alberta were so declared by order of the Minister under s. 10 of the Public Lands Act on April 5, 1989.

R.S.A. 1980 , c. P-8, s. 3(1)(e).

Alta. Reg. 122/87, s. 2(1)(f).

Supra note 387, s. 5. 


\section{J. MISCELLANEOUS LEGISLATION}

Various provisions in other legislation, which could be interpreted to allow addressing of biodiversity, involve the power to make grants. For example, s. 3(d) of the Alberta Sport, Recreation, Parks and Wildlife Foundation Act ${ }^{390}$ and the generic powers of ministers in the new Government Organization $A c t^{311}$ to make grants if authorized by Lieutenant-Governor-in-Council regulations might allow research and/or programmatic funding relevant to biodiversity to be provided by ministers responsible for Agriculture, Food and Rural Development, Forestry, Lands and Wildlife, Tourism, Parks and Recreation and Environmental Protection.

Although the thrust of the Historical Resources Act is toward the preservation of human-created objects, the definition of historical resources theoretically could permit an interested minister to help preserve biological diversity: "any work of nature ... primarily of value ... for its ... natural, scientific or aesthetic interest. ${ }^{1392}$ One possibility under this Act is a process whereby the Minister may designate a Provincial Historic Resource, whereupon no person is allowed to destroy, disturb or alter it without the Minister's permission. ${ }^{393}$ This somewhat drastic power is less likely to be used than s. 25 of the Act, which enables covenants to be entered into by an owner and the Minister, a municipal council, the Alberta Historical Resources Foundation, or an historical organization approved by the Minister. Thus, arrangements could be made for biological conservation and without the need for a dominant tenement. The Minister may also acquire historic sites by gift, purchase or lease ${ }^{394}$ and may accept gifts (or bequests or devises) of scientifically interesting sites. ${ }^{395}$

No activity under this $A c t$ is known to have been undertaken to enhance biodiversity.

\section{K. SUMMARY}

Let us now summarize the situation in Alberta regarding biological diversity. The ecosystem approach to conservation is not prominent at all. Our survey shows defects in protected areas legislation. Very little of Alberta's area is protected significantly, unless the land is in a National Park. As for areas purportedly protected, the Willmore Wilderness Parks Act has been inadequate and protection of natural areas under the Wilderness Areas, Ecological Reserves and Natural Areas Act is questionable. Provincial parks legislation does not offer much protection for biological diversity either. and wildlife programs, facilities and services."

Supra note 344, s. 13. 20). 
Considerable promise is shown in the administration of some Acts, such as the EPEA, Natural Resources Conservation Board Act and energy legislation. At the same time, a consistent lack of specific duties and criteria for their exercise in Alberta's laws permits decisions adverse to biodiversity. It depends on the perspective of various board members.

The new Alberta planning legislation does not offer much hope for innovation in habitat preservation. Certainly its provisions regarding environmental reserve offer little support for biodiversity. Provisions in the Historical Resources Act do offer interesting possibilities, were they to be included in legislation more specifically directed to the conservation of biological diversity.

The Albertan belief that economic development is of prime importance shows in various statutes and regulations, including those concerning agriculture, forest and mineral exploitation. Thus, the possibility exists in resource exploitation areas for significant adverse impacts to be allowed, or even encouraged, under such statutes as the Public Lands Act, Water Resources Act, Forests Act and the Mines and Minerals Act. In some cases, public funds are available for activities which will diminish biodiversity.

All in all, considerable work needs to be done in Alberta if the preservation of biological diversity is seen as important. The next section proposes possible improvements.

\section{RECOMMENDED LEGAL REFORMS}

A concerned government could enact many significant reforms. Relevant statutes could have explicit purpose sections. ${ }^{396}$ A duty could be imposed on all decisionmakers to assess the implications of all actions for their sustainability and effect on biological diversity. In case of uncertainty, the precautionary principle would be followed: that is, any action threatening to contribute to a significant reduction in biological diversity would not be allowed. Perhaps more specific criteria should be legislated in various Acts to effect this policy. Thus, dispositions and management decisions under such Acts as the Public Lands Act, Water Resources Act, Forests Act and the Mines and Minerals Act would be constrained. Along these lines, the prevention of reduction in biodiversity, rather than compensation or restoration after the damage, should be stressed. In respect of forests, the new British Columbia Forest Practices $\operatorname{Code}^{397}$ could be a useful starting point for new legislation.

E.g., Rankin \& M'Gonigle, supra note 4 at 326 suggest a purpose "to protect the lands, waters and resources of the province for the benefit of present and future generations by preserving ... the diversity of plant and animal communities and by maintaining the integrity of biological processes." Given the thrust of our present subject, 1 shall not engage in a critique of the concept of "integrity" (see D. Wicklum \& R. Davies, "Ecosystem Health and Integrity?" Cdn. J. Bot. (forthcoming, 1995)). mentioned as a management objective in ss. 2, 206. 
Regulations such as the Public Grazing Lands Range Improvement Regulation, which offer public funds for actions reducing biodiversity, should be repealed.

The Special Places 2000 recommendations could be implemented through a considerably amended Wilderness Areas, Ecological Reserves and Natural Areas Act. Better yet, new, omnibus protected areas legislation is highly desirable. Such an Endangered Ecosystems and Natural Areas Reserve Act, designed to ensure the preservation and functioning of endangered natural systems, should impose a duty and timetable for completing a quantified network of protected areas. Given the pace of biodiversity losses, implementation timetables and development freezes, where appropriate, might be considered for all conservation legislation. The crucial point is, of course, that conservation objectives should not be compromised by other management objectives.

At the same time, "the idea of nature conservation without the cooperation of private property owners and the general public is utopian." ${ }^{398}$ This point is of primordial importance and is highlighted by the present controversy about uncontrolled logging on privately owned land in the province. Preserving biological diversity on private land could involve the use of planning legislation. Statutory plans and land-use by-laws prepared under the planning legislation could be required to consider habitat capability of land and approval officers could be mandated to require measures to maintain or enhance it. More rigorous landscape design criteria could be imposed and encouragement could be given for the maintenance of native species, rather than the input-intensive artificial landscape of domestic grass lawns.

Even more basic would be the preparation of provincial ecosystem and vegetation maps. This information could be used to prepare binding ${ }^{399}$ regional land use classifications to guide the implementation on both Crown and private land of the proposed system of reserves, buffer zones, wildlife corridors and multi-use areas referred to earlier. ${ }^{400}$

Ontario's approach is worthy of consideration. Recent amendments to its Planning $A c t^{401}$ involve increased provincial guidance for the planning process. Comprehensive policy statements such as the following specifically support biodiversity values:

1.2 (a) Development will not be permitted in significant ravine, valley, river and stream corridors, and in significant portions of the habitat of endangered species and threatened species.

H.K. Onnes, "The Role of Landowners" in G. Bennett, ed., supra note 2 at 152.

Rankin and M'Gonigle, supra note 4 at 298-99, document "the vagaries involved in establishing a protected areas system under policy guidelines rather than legislative provisions." See text following supra note 88.

Bill 163, An Act to revise the Ontario Planning and Development Act and the Municipal Conflict of Interest Act, to amend the Planning Act and the Municipal Act and to amend other statutes related to planning and municipal matters, 3d. sess., 35th Leg., 1994. 
1.4 In decisions regarding development, every opportunity should be taken to maintain the quality of ... biota; maintain biodiversity compatible with indigenous natural systems; and protect natural links and corridors. ${ }^{402}$

One possible improvement, however, would be the consistent use of mandatory language.

Other jurisdictions in North America have also developed state-level plans to provide a framework for local planning and development decisions. ${ }^{403}$

The amendments to Alberta's planning legislation do not compare favourably with the suggestions made above. This legislation should also be amended to allow the exaction of environmental reserve for habitat protection. More needs to be done, however, than amending the planning legislation. Incentive programs will be needed to encourage private property owners to set aside habitat areas. ${ }^{404}$ Caution needs to be exercised, however, to ensure that a patchwork of different provisions does not conflict with the overall public planning strategy. ${ }^{405}$ Legislation is desirable to encourage donation of private lands to conservation organizations. As well, such organizations, and local governments, need broader authorization to obtain and enforce restrictive covenants and easements "in gross," over a part or whole of a parcel, without owning land benefited thereby (a dominant tenement). ${ }^{406}$ The Historical Resources Act allows of Municipal Affairs, 1994) [emphasis in original].

D.L. Callies, "The Quiet Revolution Revisited: A Quarter Century of Progress" (1994) 26 Urb. Lawyer 197.

404 In appropriate circumstances, allowing compensation could make it easier for an agency to exercise more caution in granting approvals. Farrier cites the experience under the South Australian Native Vegetation Management $A c t$, where providing for compensation, instead of merely conventional command and control measures, changed an 80 percent approval rate to a 94 percent refusal rate (D. Farrier, "Conserving Biodiversity on Private Land" (August 1994) 32 Resource Law Notes 5 at 90). Ibid. at 6.

For a suggested enactment, see A.J. Kwasniak, "Facilitating Conservation: Private Conservancy Law Reform" (1993) 31 Alta. L. Rev. 607 in Appendix; or Alberta 1993 Bill 211, a Private Member's Bill introduced by B. Collingwood, MLA for Sherwood Park. See also A.J. Kwasniak, ed., Private Conservancy: the Path to Law Reform (Edmonton: Environmental Law Centre, 1994); and B. Findlay \& A. Hillyer, Here Today, Here Tomorrow (Vancouver: West Coast Environmental Law Research Foundation, 1994).

The subdivision registration requirements of the Planning Act (s. 86) might complicate the acquisition and registration of a habitat area which is part of a larger parcel.

In some jurisdictions, property tax provisions discourage gifts to voluntary conservation organizations, but in Alberta this is not an important factor. See M. Denhez, You Can't Give It Away: Tax Aspects of Ecologically Sensitive Lands (Ottawa: North American Wetlands Conservation Council, 1992) at 32. The February 25, 1995 Federal budget proposed to remove the 20 percent of net income limit on charitable donations of ecologically sensitive land (Schultz \& Leong, Chartered Accountants, 1995 Federal Budget Commentary at 10 (27 Feb. 1995)).

Income tax implications of donating a conservation easement have to be considered: see Findlay \& Hillyer, ibid. at $168-71$. 
this, but it would be more appropriate if the wording were used in an amendment to expand the present s. 22 of EPEA. One desirable change to the present wording of the Historical Resources Act's s. 25, however, would be to remove the Minister's power to discharge or modify the covenant. Permanent protection is important.

If private property crucial to a corridor or ecosystem could not be acquired through a voluntary easement program, further regulation, or expropriation of the necessary estate in the land might also be merited. Again, s. 16 of the Historical Resources $A c t^{407}$ would be a useful precedent for such legislation.

Various initiatives in other countries should also be examined. For example, the European Community allows farmers who undertake environmentally sound farming practices (including long-term dedication for conservation purposes) to gain additional income. By 1997 it is expected that up to 2 billion European Currency Units will be allocated for this purpose. ${ }^{408}$ This approach is in stark contrast to the destructive effects of the Canadian Wheat Board Act ${ }^{409}$ and the Western Grain Stabilization $A c t,{ }^{410}$ whose regimes encourage farmers to plant maximum acreage, including marginal land. 411

Along these lines, legislation could be enacted to offer cost-sharing for conservation measures, in the first instance to prevent new land from being converted to crops, but also, if feasible, to encourage the reconversion of cropland to natural habitat. Ongoing management costs should also be covered. One approach is the so-called "Swampbuster" provision in the U.S. Food Security Act, which makes a farmer ineligible for price supports, certain loans, crop insurance and disaster payments "for any year in which an annual crop is grown on converted wetlands." ${ }^{412}$ Of course, a broader provision than this would be desirable, as this enactment addresses the loss of wetlands only from cropping, not from other activities. As well, financial incentives, not merely disincentives, should be incorporated into such an approach. A useful example is Alberta's Habitat Program 1986-89, a pilot under which incentives

It is of interest to note that s. 71 of the Land Titles Act, R.S.A. 1980, c. L-5 removes the common law requirement that dominant and servient tenements belong to different persons. One example of its use is the "Restrictive Covenants and Easement Agreement" between Stone Creek Properties and the Town of Canmore, which is soon to be executed.

wo See text accompanying supra notes $393,394$.

408 Community Regulation 2078/92 (C. Stauffmann, "The European Community and EECONET," in Bennett, ed., supra note 2 at 207-08.) An ECU (European Currency Unit) is the equivalent of C\$1.70.

R.S.C. 1985 , c. C-24.

410 R.S.C. 1985 , c. W-7.

411 Tkachuk, supra note 186 at 10. He claims that the Canadian Wheat Board Act is "[p]robably the single most destructive piece of federal legislation with respect to wetland habitat" (ibid.) and the point is probably equally applicable to other wildlife habitat.

See also G.C. van Kooten, "Preservation of Waterfowl Habitat in Western Canada: Is The North American Waterfowl Management Plan A Success?" (1992) 32 Nat. Res. J. 758, who gives other examples of Canadian policies inimical to wetlands preservation (at 764-66). describes (and criticizes) both "swampbuster" and the less rigorous "sodbuster" provisions in American farm legislation. 
amounting to 80 percent of the rental value of agricultural land were paid for retaining wildlife habitat. In the counties where this was tried, over 16,000 hectares of habitat were preserved. ${ }^{413}$

Consideration should also be given to enacting endangered species legislation, perhaps based on the American ESA, but with some modification. For example, more specific provisions could be made to ensure that both the destruction of endangered wildlife habitat and the destruction or removal of endangered flora on private property are illegal. ${ }^{414}$ The Manitoba Endangered Species $A c t^{15}$ might also be a useful precedent:

2(1) The purposes of this Act are:

(a) to ensure the protection and to enhance the survival of endangered and threatened species in the province;

3(1) This act applies to species ... occurring on private lands.

10(1) No person shall

(a) kill, injure, disturb or interfere with an endangered species, a threatened species or an extirpated species which has been reintroduced;

(b) destroy, disturb or interfere with the habitat of ... [such] species;

(c) damage, destroy, obstruct or remove a natural resource on which ... [such] species depends

for its life and propagation.

Unlike the British Columbia Wildlife Act, ${ }^{416}$ however, it is important to ensure that plants and invertebrates are protected.

In line with earlier comments about global pollution and climate-change issues, Alberta should re-examine the EPEA and other statutes to ensure that the regulation of the manufacture, transport, export or emission of substances harmful to biodiversity is sufficiently rigorous. ${ }^{47}$ Energy conservation and other measures need enactment to deal with the emission of gases implicated in global climate change.

Space constraints preclude analysis of other possibilities mentioned by Rankin and M'Gonigle, ${ }^{418}$ such as constitutional clauses requiring environmental protection, implementing the public trust (as is being done, e.g., in the Yukon ${ }^{419}$ and Northwest 
Territories, ${ }^{420}$ with concomitant citizen standing in the courts), system-wide planning for reserve areas, ${ }^{421}$ cooperation toward international designation of reserve areas and a Commissioner for the Environment.

Another interesting issue is whether development and conservation planning should be integrated into the same agency (the Brundtland Report would seem to favour $\operatorname{such}^{422}$ ) or separated. Since decisions of agencies with economic mandates can have such devastating effects on biological diversity, either they must have a statutory duty to consider such impacts or an independent agency should be established to mediate apparent conflicts between development and conservation values. The latter approach seems to have been adopted in New Zealand's comprehensive Resource Management Act of $1991^{423}$ and Rankin and M'Gonigle think that "[a]n independent body with clear authority to review environmental and land use decisions is vital to effective conservation planning." ${ }^{424}$ The Alberta solution, if superadded environmental responsibilities were to be imposed on development agencies as was suggested above, would be to combine the approaches, retaining and clarifying the AEUB and NRCB mandates.

The unifying concept suggested here for legislative reform has been the ecosystem approach to conservation. If this perspective were to be employed consistently, Alberta could lead the nation's efforts to conserve and enhance Canada's biological diversity.

\section{CONCLUSION}

The public perception of conservation and biodiversity issues has been shaped by the important relationship between sustainable development and biodiversity. The breadth and vagueness of the former term, however, has allowed remarkable shipmates to coexist on "Sustainable Spaceship Earth." The Brundtland Report is partly responsible, since this consensus-seeking document had to acknowledge the desperate need for (ecologically and socially sustainable) economic development in the poor countries of the world. Unfortunately, the report's unrealistic and dangerous endorsement of continual compounded growth (4 percent per year, ${ }^{425}$ with a doubling time of eighteen years) has allowed some to talk about "sustainable economic growth." It is here contended that any growth with significant adverse effects on biological diversity should be rejected as unsustainable. ${ }^{426}$ The radical implications of this, including the necessary redistribution of world income if global equity is to be achieved, understandably makes many people pessimistic about humanity's ability to solve the

S.N.W.T. 1990, c. 38, s. 6.

421 See e.g. the Manitoba Provincial Parks Amendment Act, S.M. 1993, c. 39.

422 G.H. Bruntland, ed., Our Common Future: the World Commission on Environment and Development (Oxford: Oxford University Press, 1987) at 312. N.Z.S. 1991, \#69. Careful analysis of New Zealand's experience with this approach would help Alberta policy makers.

426 This blanket statement should be understood to imply consideration of an indefinite timescale and at least a regional geographic perspective. See Imboden, supra note 95 at 66. 
biological diversity crisis. How can we stop the activities which result in our losing many thousands of species each year?

Changes in our values and lifestyles, a fundamental rethink of many facets of our global exchange economy, and a painful rethink of personal freedoms so often exercised at the expense of the environment, would inevitably be necessary if we were to seek policies and strategies that are really going to make a difference to conservation..... ${ }^{427}$ 